Prepared in cooperation with the Bradford County Conservation District

\title{
Comparison of Regression Relations of Bankfull Discharge and Channel Geometry for the Glaciated and Nonglaciated Settings of Pennsylvania and Southern New York
}

Scientific - nvestigations Report $2018-5066$ 4. Version 11, July 2020

U.S. Department of the interior U.S. Geological Survey. 
Cover. Glaciated geomorphology along the West Branch Lackawaxen near Aldenville, Pa. (U.S. Geological Survey streamflow gage 01428750). Photograph by Paul L. O'Hara, Pleasant Mount, Pa. 


\section{Comparison of Regression Relations of Bankfull Discharge and Channel Geometry for the Glaciated and Nonglaciated Settings of Pennsylvania and Southern New York}

By John W. Clune, Jeffrey J. Chaplin, and Kirk E. White

Prepared in cooperation with the Bradford County Conservation District

Scientific Investigations Report 2018-5066

Version 1.1, July 2020 


\title{
U.S. Department of the Interior \\ RYAN K. ZINKE, Secretary
}

\section{U.S. Geological Survey James F. Reilly II, Director}

\author{
U.S. Geological Survey, Reston, Virginia: 2018 \\ First release: 2018 \\ Revised: July 2020 (ver 1.1)
}

\begin{abstract}
For more information on the USGS - the Federal source for science about the Earth, its natural and living resources, natural hazards, and the environment-visit https://www.usgs.gov or call 1-888-ASK-USGS.

For an overview of USGS information products, including maps, imagery, and publications, visit https://store.usgs.gov.
\end{abstract}

Any use of trade, firm, or product names is for descriptive purposes only and does not imply endorsement by the U.S. Government.

Although this information product, for the most part, is in the public domain, it also may contain copyrighted materials as noted in the text. Permission to reproduce copyrighted items must be secured from the copyright owner.

Suggested citation:

Clune, J.W., Chaplin, J.J., and White, K.E., 2018, Comparison of regression relations of bankfull discharge and channel geometry for the glaciated and nonglaciated settings of Pennsylvania and southern New York (ver. 1.1, July 2020): U.S. Geological Survey Scientific Investigations Report 2018-5066, 20 p., https://doi.org/10.3133/ sir20185066. 


\section{Acknowledgments}

This project was funded by the National Fish and Wildlife Foundation under a cooperative agreement with the Bradford County Conservation District (BCCD). The authors would like to thank Michael Lovegreen, lan Lathrop, Catherine Yeakel, and Joseph Quatrini of BCCD for making this study possible. Sincere appreciation is extended to U.S. Geological Survey colleagues for the geomorphic assessments conducted by Scott Sorber and Kyle Ohnstad; report review by Tammy Zimmerman, Barry Baldigo, Peter Cinotto, and Christiane Mulvihill; and StreamStats analysis performed by Kernell Ries, Peter McCarthy, Katharine Kolb, Peter Steeves, Todd Koenig, Ryan Thompson, and Scott Hoffman. 


\section{Contents}

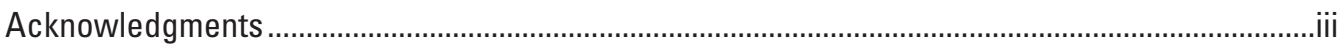

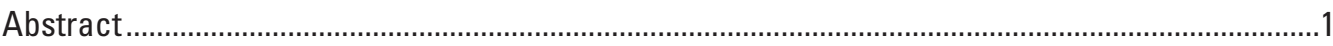

Introduction

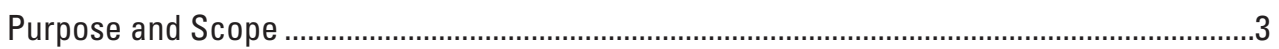

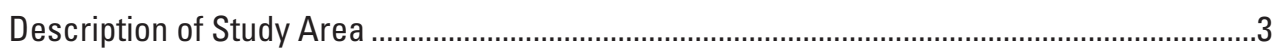

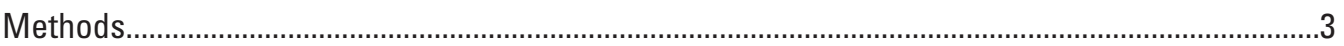

Regression Relations of Bankfull Discharge and Channel Geometry..............................................

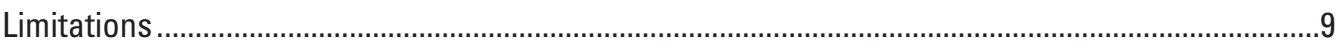

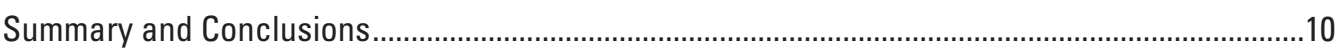

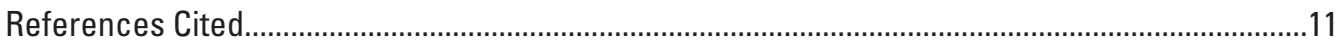

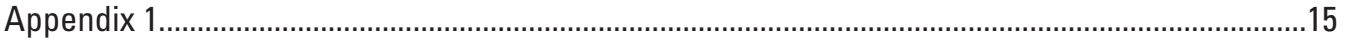

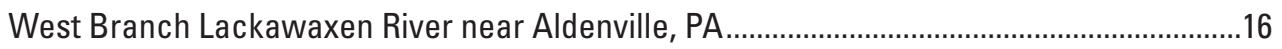

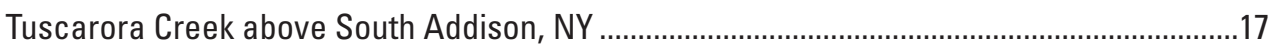

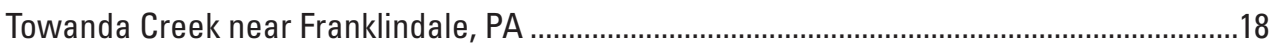

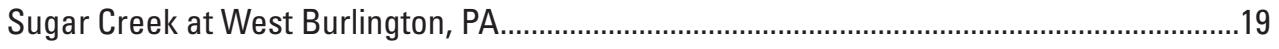

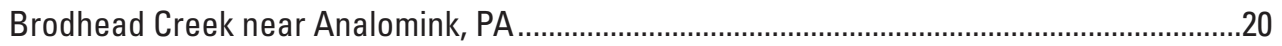




\section{Figures}

1. Photograph showing streambank erosion in the glaciated setting of Bradford County, Pennsylvania .

2. Map showing location of the noncarbonate and carbonate bedrock settings, maximum extent of Wisconsinan glaciation, and selected glaciated and unglaciated streamflow-gaging stations for regional curves development and comparison in Pennsylvania and southern New York

3. Graphs showing distribution of sites, drainage area, recurrence interval, bankfull discharge, cross-sectional area, mean depth and width for the glaciated and unglaciated settings of Pennsylvania and southern New York

4. Graphs showing drainage area in relation to $A$, bankfull discharge, $B$, crosssectional area, $C$, width, and $D$, mean depth for the glaciated setting of Pennsylvania and southern New York

5. Graphs showing drainage area in relation to $A$, bankfull discharge, $B$, crosssectional area, $C$, width, and $D$, mean depth for the noncarbonate glaciated and unglaciated settings of Pennsylvania and southern New York.

6. Graphs showing drainage area in relation to $A$, bankfull discharge, $B$, crosssectional area, $C$, width, and $D$, mean depth for the noncarbonate and carbonate settings for streams in Pennsylvania and selected areas of Maryland

7. Diagram showing geomorphic reference points of bankfull, active-channel, and depositional bar

\section{Tables}

1. Channel characteristics of the 2016 geomorphic assessments for select streamflow-gaging stations in the glaciated setting of Pennsylvania and southern New York

2. Results of analysis of covariance (ANCOVA) test for differences in slope and intercept among glaciated and unglaciated noncarbonate settings of Pennsylvania and New York 


\section{Conversion Factors}

International System of Units to U.S. customary units

\begin{tabular}{|c|c|c|}
\hline Multiply & By & To obtain \\
\hline \multicolumn{3}{|c|}{ Length } \\
\hline meter $(\mathrm{m})$ & 3.281 & foot $(\mathrm{ft})$ \\
\hline kilometer $(\mathrm{km})$ & 0.6214 & mile (mi) \\
\hline \multicolumn{3}{|c|}{ Area } \\
\hline square meter $\left(\mathrm{m}^{2}\right)$ & 10.76 & square foot $\left(\mathrm{ft}^{2}\right)$ \\
\hline \multicolumn{3}{|c|}{ Volume } \\
\hline cubic meter $\left(\mathrm{m}^{3}\right)$ & 264.2 & gallon (gal) \\
\hline cubic meter $\left(\mathrm{m}^{3}\right)$ & 35.31 & cubic foot $\left(\mathrm{ft}^{3}\right)$ \\
\hline \multicolumn{3}{|c|}{ Flow rate } \\
\hline meter per second $(\mathrm{m} / \mathrm{s})$ & 3.281 & foot per second ( $\mathrm{ft} / \mathrm{s})$ \\
\hline cubic meter per second $\left(\mathrm{m}^{3} / \mathrm{s}\right)$ & 35.31 & cubic foot per second $\left(\mathrm{ft}^{3} / \mathrm{s}\right)$ \\
\hline
\end{tabular}

\section{Datum}

Vertical coordinate information is reference to the North American Vertical Datum of 1988 (NAVD 88).

Horizontal coordinate information is referenced to the North American Datum of 1983 (NAD 83).

Altitude, as used in this report, refers to distance above the vertical datum. 


\title{
Comparison of Regression Relations of Bankfull Discharge and Channel Geometry for the Glaciated and Nonglaciated Settings of Pennsylvania and Southern New York
}

\author{
By John W. Clune, Jeffery J. Chaplin, and Kirk E. White
}

\begin{abstract}
Streambank erosion in areas of past glacial deposition has been shown to be a dominant source of sediment to streams. Water resource managers are faced with the challenge of developing long and short term (emergency) stream restoration efforts that rely on the most suitable channel geometry for project design. A geomorphic dataset of new $(2016, n=5)$ and previous (1999-2006, $n=96$ ) estimates of bankfull discharge and channel dimensions at U.S. Geological Survey streamflow-gaging stations was compiled to present and contrast the glaciated and unglaciated noncarbonate settings of southern New York and Pennsylvania that included selected areas of Maryland. Empirical models were developed by using simple linear regressions that relate bankfull discharge and channel geometry to drainage area (regional curves). Significant relations $(p<0.05)$ were able to explain variability with coefficient of determination $\left(R^{2}\right)$ values of 0.89 for bankfull discharge, 0.94 for cross-sectional area, 0.87 for bankfull width, and 0.83 for bankfull depth. These regression relations for the glaciated noncarbonate settings of northern Pennsylvania and southern New York were able to provide a slightly better fit than regional curve models developed previously for the entire noncarbonate region of Pennsylvania. Although, the analysis of covariance (ANCOVA) results for comparison between regression equations for the glaciated and unglaciated settings showed that except for the significant intercept of bankfull discharge versus drainage area $(F=8.26, p$-value $<0.005)$, the regression equations are not significantly different between the glaciated and unglaciated setting of Pennsylvania and southern New York. Therefore, data stratification by glaciation does not improve regional curves relations developed previously for the noncarbonate (glaciated and unglaciated) and carbonate settings of Pennsylvania and Maryland. Further analysis that incorporates data stratification or multivariate approaches based on mean annual runoff, precipitation, slope, stream classification, or other relevant parameters may optimize the accuracy and utility of statewide models. The new estimates
\end{abstract}

of bankfull discharge and channel dimensions at streamflowgaging sites and updated drainage areas from StreamStats were incorporated into previously developed regional curves to produce an updated set of regression relations of bankfull discharge and channel geometry for the noncarbonate and carbonate settings of Pennsylvania and Maryland.

\section{Introduction}

The seventh leading cause of impairment to assessed streams and rivers in the Nation is sediment (U.S. Environmental Protection Agency, 2009). Historically, the major legacy sediment inputs to streams have resulted from deforestation, loss of beaver wetland habitat, and water-powered mill dams (Miller, 1986; Naiman and others, 1988; MüllerSchwarze and Sun, 2003; Walter and Merritts, 2008; Bain and others, 2012; James, 2013), but currently in the Chesapeake Bay watershed for example, the greatest amount of sediment is generated from urban and agricultural settings (Gellis and other, 2009; Brakebill and others, 2010). Although upland erosion can be a major contributor to soil loss (Clune and others, 2010), streambank erosion has also been shown to be a significant source of suspended sediment in streams (Gellis and others, 2004; Gellis and others, 2015). In particular, streambank erosion in areas of past glacial deposition has been shown to be a dominant source of sediment to streams (fig. 1) (Gordon, 1979; Ashmore, 1993; Sekely and others, 2002; Nagle and others, 2007). Sediment, and particles that adhere to its surfaces (for example, particles containing phosphorus), can cause downstream damage to aquatic biota, water treatment facilities, reservoir capacity, and estuaries (Dearmont and others, 1998; Henley and others, 2000; Langland, 2015). Restoring unstable stream morphology in the continental United States costs more than $\$ 1$ billion per year (Bernhardt, 2005).

Management strategies to minimize and reduce streambank erosion in order to maintain stable and biologically productive (unimpaired) watersheds include watershed 


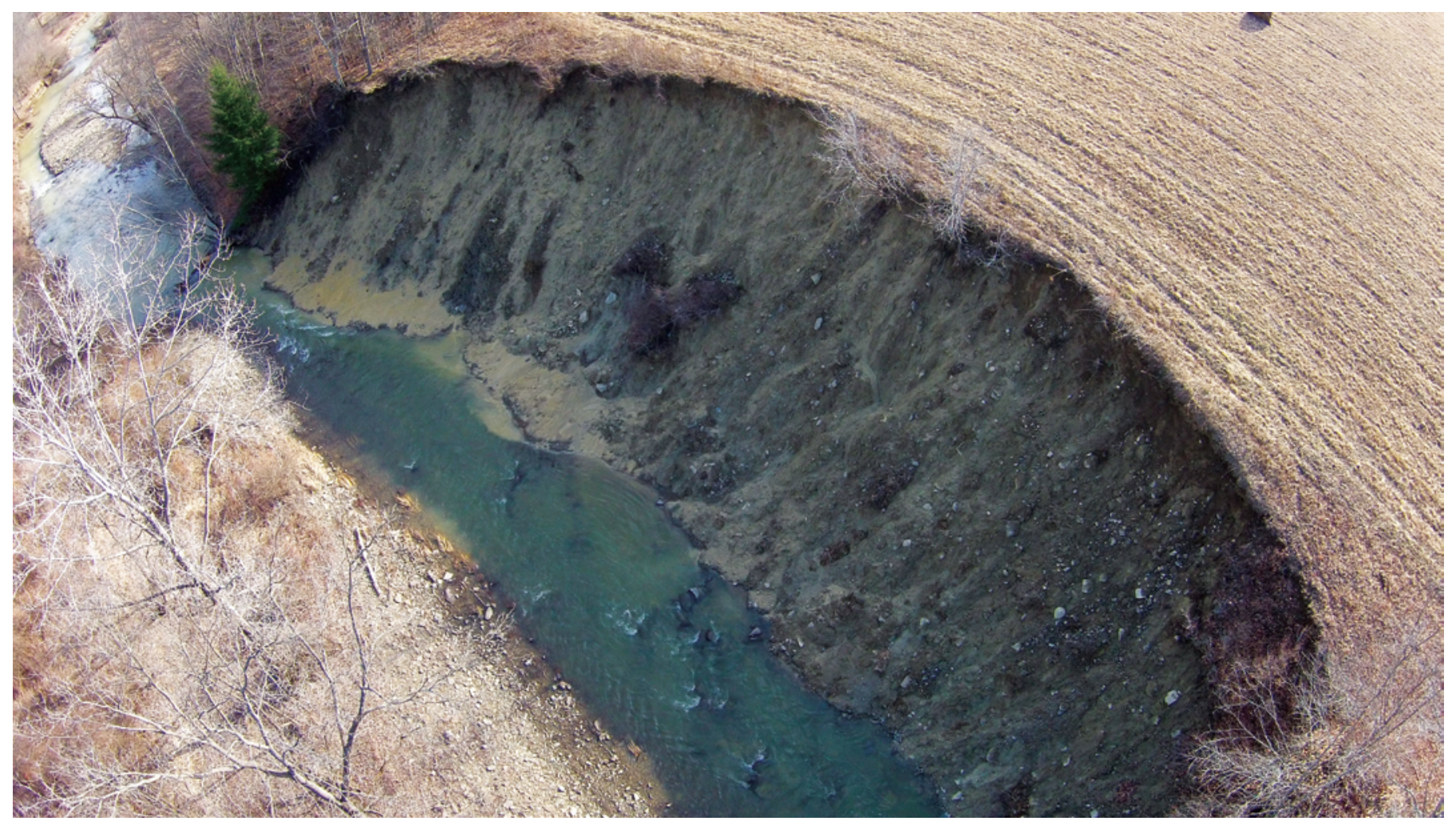

Figure 1. Streambank erosion in the glaciated setting of Bradford County, Pennsylvania. Photograph taken by Joseph Quatrini, Bradford County Conservation District.

planning, storm water controls, riparian buffers, and streambank stabilization (Federal Interagency Stream Restoration Working Group, 1998). Streambank stabilization techniques include traditional armoring and natural stream design (Rosgen, 1997; Bernard and others, 2007). Designs for stream restoration efforts often rely on established relations between stream channel dimensions and the surrounding drainage area (Rosgen, 1996). Stream channel dimensions are shaped by a dominant, reoccurring streamflow that transports and deposits most of the sediment during the point when a stream becomes full and begins to overtop its banks (Leopold and others,

1964; Leopold, 1992). This bankfull discharge often occurs at a relative frequency of every 1-2 years to form the channel morphology (Wolman and Miller, 1960; Dunne and Leopold, 1978). Bankfull discharge and channel dimensions for a given stream can be estimated by using established regression equations that relate bankfull discharge and channel geometry to drainage area, and serve as ancillary information to aid the design of stream restoration projects (Rosgen, 1996).

Early studies used regression equations to develop sediment discharge relations for a range of drainage areas (Leopold and Maddock, 1953). More specific relations have been developed to create regional curves that aid states with stream classification and assessment, as well as design of restoration projects (Somerville, 2010; U.S. Department of Agriculture, 2017). In New York, regional curves were developed based on eight hydrologic regions for which only region 3 differed significantly ( $p$-value $<0.05$ ) from the other regions (Lumia, 1991; Mulvihill and others, 2005, 2007, 2009; Westergard and others, 2005; Mulvihill and Baldigo, 2007). Despite more accurate regional curves based on other covariable models (for example, mean annual runoff), data stratification by hydroregions that were derived with determinate, unbiased, and reproducible procedures has shown the most advantage to resource managers by providing better overall coefficients of determination $\left(R^{2}\right)$ and standard errors of estimate (SEE) (Mulvihill and Baldigo, 2012). Regional curves for Pennsylvania were first published for the Piedmont Physiographic Province (White, 2001; Cinotto, 2003) region and later combined with the all physiographic provinces within the state to produce significant regression relations for the carbonate and noncarbonate settings (Chaplin, 2005). National approaches to optimize regional curves continue to use a combination of data stratification methods (Keaton and others, 2005) and have found that considering precipitation and runoff as explanatory variables can improve bankfull relations (Wilkerson and others, 2014). 
The research described in this report builds upon the previous national and regional curve development approaches by assessing whether regression relations of bankfull discharge and channel geometry stratified by glaciation further minimizes variability for Pennsylvania and southern New York. The results of this study will serve the needs of water resource managers in Pennsylvania that are faced with the challenge of developing long and short term (emergency) stream restoration efforts and need to utilize natural stream design techniques that rely on the most suitable channel geometry (Bradford County Conservation District, 2013). This study was conducted by the U.S. Geological Survey (USGS) in cooperation with the Bradford County Conservation District as part of an effort to provide an evaluation of the most reliable model estimates and predictions of bankfull discharge and channel geometry to aid classification, monitoring, and restoration efforts of streams in the glaciated areas of Pennsylvania and southern New York. This research is part of a larger effort to incorporate regional curves for Pennsylvania into the USGS StreamStats web application, which provides online streamflow and basin characteristics for ungaged sites and can be used by stream rehabilitation personnel to provide publicly accessible and reproducible estimates of stream channel dimensions (Ries III and others, 2004, 2008).

\section{Purpose and Scope}

The purpose of this report is to (1) present regional relations of bankfull discharge and channel dimensions with drainage area for the glaciated settings of Pennsylvania and southern New York, and (2) compare these relations with the unglaciated setting of Pennsylvania. These objectives were met by analyzing geomorphic data previously collected along stream reaches from 96 streamflow-gaging stations between 1999 and 2006 in Pennsylvania and New York, and from five additional sites in Pennsylvania during the summer of 2016. A synthesized geomorphic dataset of the new and previous estimates of bankfull discharge, width, depth, and cross-sectional area was used to present and contrast the glaciated and unglaciated settings of Pennsylvania and southern New York.

\section{Description of Study Area}

The study area is located in the northeast region of the United States, within the states of Pennsylvania and New York. The area is underlain by consolidated carbonate and noncarbonate bedrock. Unconsolidated sediment (till, drift, and so forth) was deposited during the advance and retreat of four major periods of past glaciation (Shultz, 1999). The youngest glaciation (Wisconsinan) provides the most observable characteristics of the depositional and erosional features of the previous periods (fig. 2; Shultz, 1999).

The topography is relatively mountainous with elevations from 626 to 2,437 feet above NAVD 88 (U.S. Geological Survey, 2013a). Stream channel slopes can range from high gradient headwaters to lowland valleys. The local climate and hydrology provide a wet season of increased precipitation and runoff from March through May with low streamflow periods during June through September (Shultz, 1999). Intermediate storms provide peak discharge events from localized thunderstorms and regional hurricanes during the summer and fall months. Stream morphology ranges from steep incised valleys with limited overbank flow to lower valley areas with wider floodplains and more frequent overbank flow. Transportation corridors often follow stream channels and restrict natural meandering and floodplain areas.

\section{Methods}

Site selection and data collection for five new sites was performed during the summer of 2016 and incorporated into older datasets for regional curves of Pennsylvania and New York in order to compare noncarbonate glaciated and unglaciated settings. The site selection, data collection, and data analysis are described in the following section.

The selection of five new streamflow-gaging stations for use in channel-geometry regional-curve development was based on the following filtering criteria adapted from Chaplin (2005):

1. Glaciation-The watershed of the streamflow-gaging station must be located within the extent of the Wisconsinan glaciation.

2. Land use-The watershed of the streamflow-gaging station must not be subject to mining that alters surface and (or) underground hydrology, and land cover classified as urban development can be no greater than 20 percent.

3. Period of record-The station has to have a period of record of at least 7 years.

4. Streamflow regulation - No greater than 20 percent of the streamflow to the gaging station is subject to regulation by reservoirs, dams, and so forth.

5. Accessibility-The stream must be wadeable (drainage area $<215$ square miles $\left[\mathrm{mi}^{2}\right]$ ) in order to perform the field geomorphic survey.

A list of streamflow-gaging stations and attribute data for the glaciated setting of New York and Pennsylvania was retrieved from the USGS Automated Data Processing System (ADAPS; U.S. Geological Survey, 2013b). A spatial analysis was performed to estimate the percentage of mining, urban development, and streamflow regulation within the watershed A subset of eligible sites was produced based on the filtering criteria described above and reconnaissance was performed for each site to assess the extent of any stream channelization or armoring that would provide restrictions to overbank flow into the floodplain and obscure bankfull indicators. This final 


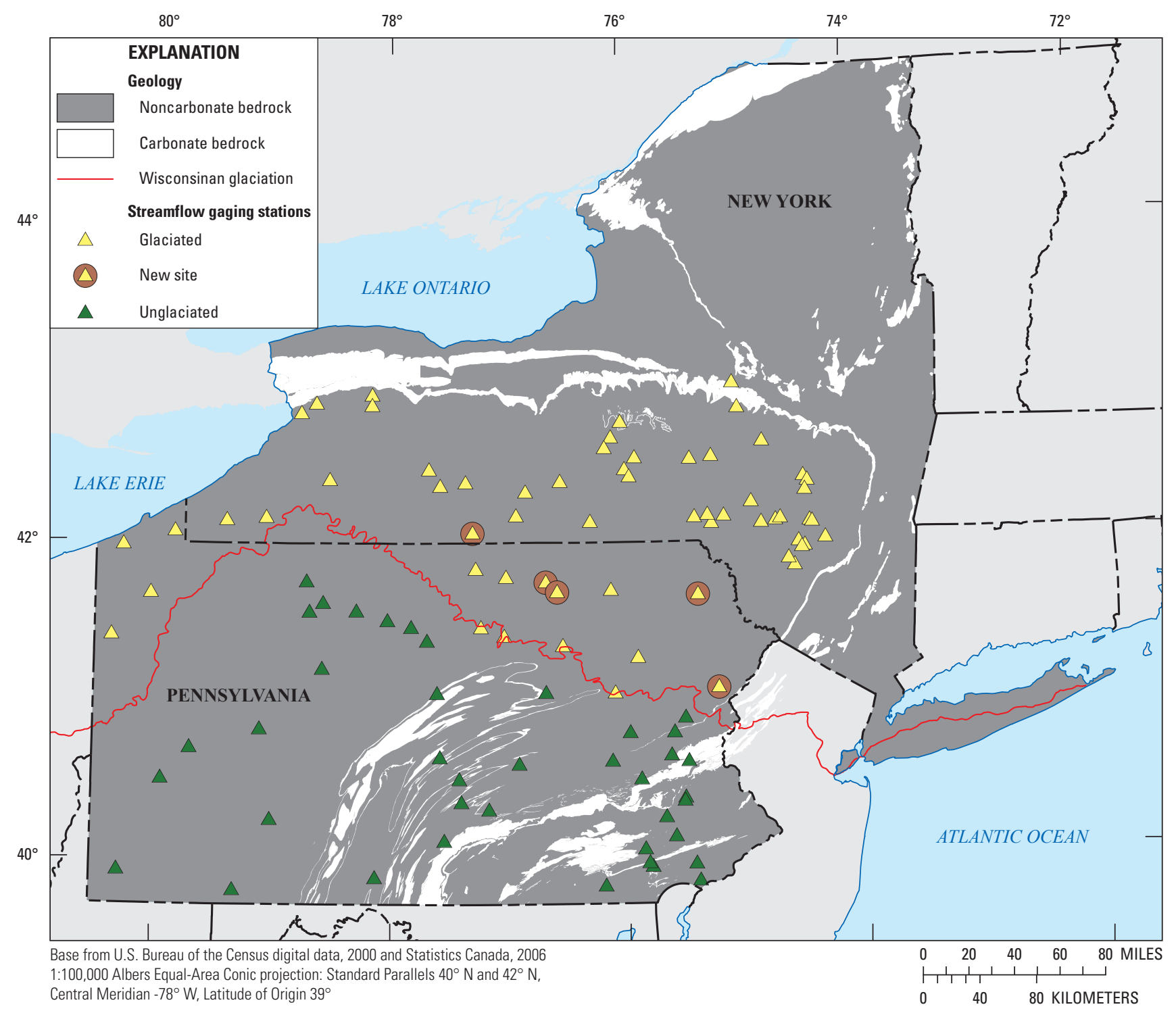

Figure 2. Location of the noncarbonate and carbonate bedrock settings, maximum extent of Wisconsinan glaciation, and selected glaciated and unglaciated streamflow-gaging stations for regional curves development and comparison in Pennsylvania and southern New York. Generalized carbonate rock dataset used for Pennsylvania StreamStats application (https://pa.water.usgs. gov/infodata/gis/carbonate_metadata.htm).

selection process produced five new sites for incorporation into the regional-curve analysis (table 1).

At each site, bankfull indicators were identified and a reach section established (Leopold and others, 1964; Harrelson and others, 1994). A longitudinal profile of each reach and two cross sections along riffles were surveyed by using standard USGS survey methods to capture the topographic features of bankfull, thalweg, and other changes of slopes (U.S. Geological Survey, 1966; Harrelson and others, 1994). Transect pebble counts were performed at each cross section to determine the particle size distribution (Wolman, 1954; Harrelson and others, 1994). Additional information collected at each site included a field sketch, photographs, and field notes.
The longitudinal profile, cross-sectional surveys, and pebble count data were used to calculate and plot the bankfull discharge and stream channel dimensions. The bankfull discharge, cross-sectional area, width, mean depth, value of the particle diameter at 50 percent in the cumulative distribution $\left(D_{50}\right)$, and geomorphic parameters were determined for each cross section. The stream classification was assigned based on Rosgen (1994). The reach channel geometry was averaged for each of the three parameters of cross-sectional area, depth, and width from the two cross sections. The bankfull and water surface at the gage was extrapolated from the longitudinal profile plot to obtain the gage height corresponding to the bankfull feature (Chaplin, 2005, p. 11). 
The new bankfull discharge and channel geometry data were combined with previously published regional curve datasets for noncarbonate sites in Pennsylvania and hydrologic regions 4, 4A, 5, and 6 of southern New York (White, 2001; Cinotto, 2003; Miller and Davis, 2003; Chaplin, 2005; Westergard and others, 2005; Mulvihill and others, 2005, 2009). Data from hydrologic region 3 in New York was excluded since this region was previously shown to differ significantly from the other regions (Mulvihill and Baldigo, 2007, 2012). There were six sites in New York in which the drainage area was greater than the $215 \mathrm{mi}^{2}$ limit used in Pennsylvania. The full range of the parameter values available was included (drainage areas from 0.7 to $332 \mathrm{mi}^{2}$ ) in the final dataset for the glaciated settings of Pennsylvania and southern New York in order to better capture variability and provide the best model fit.

A simple linear regression was used to relate drainage area to bankfull depth, width, cross-sectional area, and discharge. A log transformation of the best fit line produced a power function in which bankfull discharge and channel dimensions are a function of drainage area. To test if stratifying the data by glaciation improved previous regional curve relations, an analysis of covariance (ANCOVA) was performed to compare any differences between models (Helsel and Hirsch, 2002; Fox and Weisberg, 2011; R Core Team, 2017). Significant differences $(p$-value $<0.05)$ in slope and intercept between regression lines would indicate that separate curves would yield better estimates of channel dimensions (Chaplin, 2005).

\section{Regression Relations of Bankfull Discharge and Channel Geometry}

The bankfull discharge and channel geometry for five newly surveyed sites are shown in table 1 (See appendix 1 for the locations, photographs, and data associated with cross-sectional surveys for the five stream reaches.). These data were combined with previous regional-curve channel-geometry data developed for the glaciated settings of Pennsylvania and southern New York (fig. 3). The median recurrence interval for bankfull discharge for the glaciated setting was 1.4 years and within the typical range of 1 to 2 years for similar geomorphic studies conducted nationally (Dunne and Leopold, 1978; Lawlor, 2004) and within Pennsylvania and New York (Chaplin, 2005; Mulvihill and others, 2009).

Regional curves for the glaciated setting were based on an empirical model using a simple linear regression of drainage area versus bankfull discharge, cross-sectional area, width, and depth; these significant relations $(p$-value $<0.05)$ explained the variability with coefficients of determination $\left(R^{2}\right)$ of 0.89 , 0.94, 0.87, and 0.83, respectively (fig. 4). The log-log transformed power function for each relation is shown in figure 4 and several observations fall outside the 95 percent confidence interval. The confidence interval provides the level of certainty for which the range of values sampled encompasses the true population. The overall spread in data for the glaciated setting of Pennsylvania and southern New York is comparable to the

Table 1. Channel characteristics of the 2016 geomorphic assessments for select streamflow-gaging stations in the glaciated setting of Pennsylvania and southern New York.

$\left[\mathrm{mi}^{2}\right.$, square miles; ft, feet; $\mathrm{ft}^{3} / \mathrm{s}$, cubic feet per second; POR, period(s) of record; $\mathrm{ft}^{2}$, square feet; yrs, years; PA, Pennsylvania; NY, New York; NA, not available; cross section stream type from Rosgen (1994)]

\begin{tabular}{|c|c|c|c|c|c|c|c|c|c|c|c|}
\hline $\begin{array}{l}\text { Station } \\
\text { number }\end{array}$ & Station name & POR & $\begin{array}{c}\text { Drainage } \\
\text { area } \\
\left(\mathrm{mi}^{2}\right)\end{array}$ & $\begin{array}{l}\text { Bankfull } \\
\text { discharge } \\
\left(\mathrm{ft}^{3} / \mathrm{s}\right)\end{array}$ & $\begin{array}{l}\text { Bankfull } \\
\text { cross } \\
\text { sectional } \\
\text { area } \\
\left(\mathrm{ft}^{2}\right)\end{array}$ & $\begin{array}{l}\text { Bankfull } \\
\text { width } \\
\text { (ft) }\end{array}$ & $\begin{array}{l}\text { Bankfull } \\
\text { mean } \\
\text { depth } \\
\text { (ft) }\end{array}$ & $\begin{array}{c}\text { Recurrence } \\
\text { interval } \\
\text { (yrs) }\end{array}$ & $\begin{array}{l}\text { Reach } \\
\text { slope }\end{array}$ & $\begin{array}{c}\text { Mean } \\
D_{50}\end{array}$ & $\begin{array}{l}\text { Cross- } \\
\text { section } \\
\text { stream } \\
\text { type }\end{array}$ \\
\hline 01428750 & $\begin{array}{l}\text { West Branch } \\
\text { Lackawaxen River } \\
\text { near Aldenville, PA }\end{array}$ & 1986-present & 40.6 & 1,810 & 256.18 & 76 & 3.38 & 1.5 & 0.005 & 63 & $\mathrm{C} 4, \mathrm{C} 3$ \\
\hline 01440400 & $\begin{array}{l}\text { Brodhead Creek near } \\
\text { Analomink, PA }\end{array}$ & 1957-present & 65.9 & 2,325 & 390.25 & 115 & 3.51 & 1.4 & 0.004 & 85 & $\mathrm{C} 3, \mathrm{~F} 4$ \\
\hline 01531325 & $\begin{array}{c}\text { Sugar Creek at West } \\
\text { Burlington, PA }\end{array}$ & 2010-present & 93.6 & 2,638 & 504.74 & 149 & 3.42 & NA & 0.002 & 45 & $\mathrm{C} 4, \mathrm{C} 4$ \\
\hline 01531908 & $\begin{array}{c}\text { Towanda Creek near } \\
\text { Franklindale, PA }\end{array}$ & 2010-present & 112.0 & 3,311 & 585.61 & 129 & 4.54 & NA & 0.002 & 109 & $\mathrm{C} 3, \mathrm{C} 4$ \\
\hline
\end{tabular}




\section{Distribution of sites}

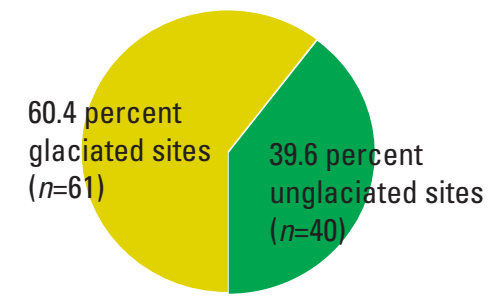

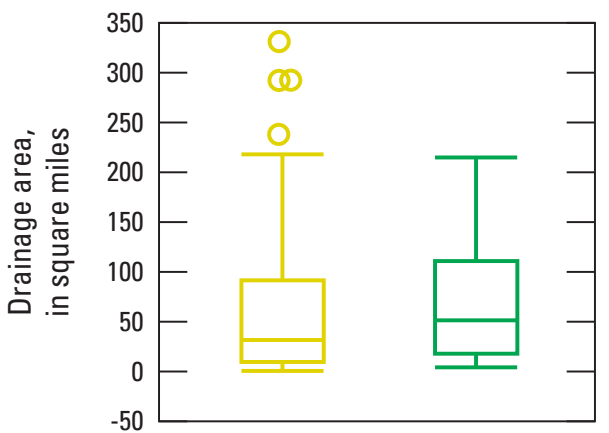
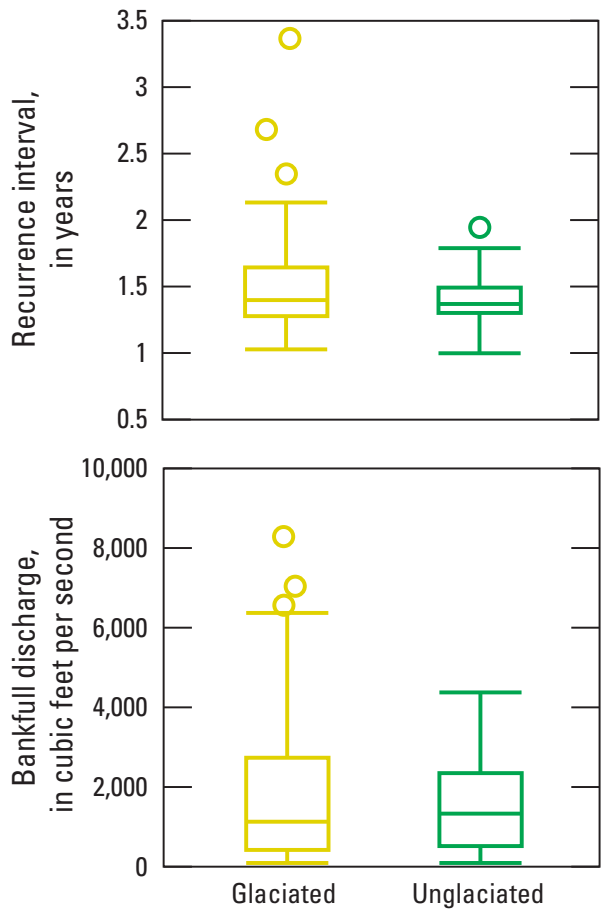
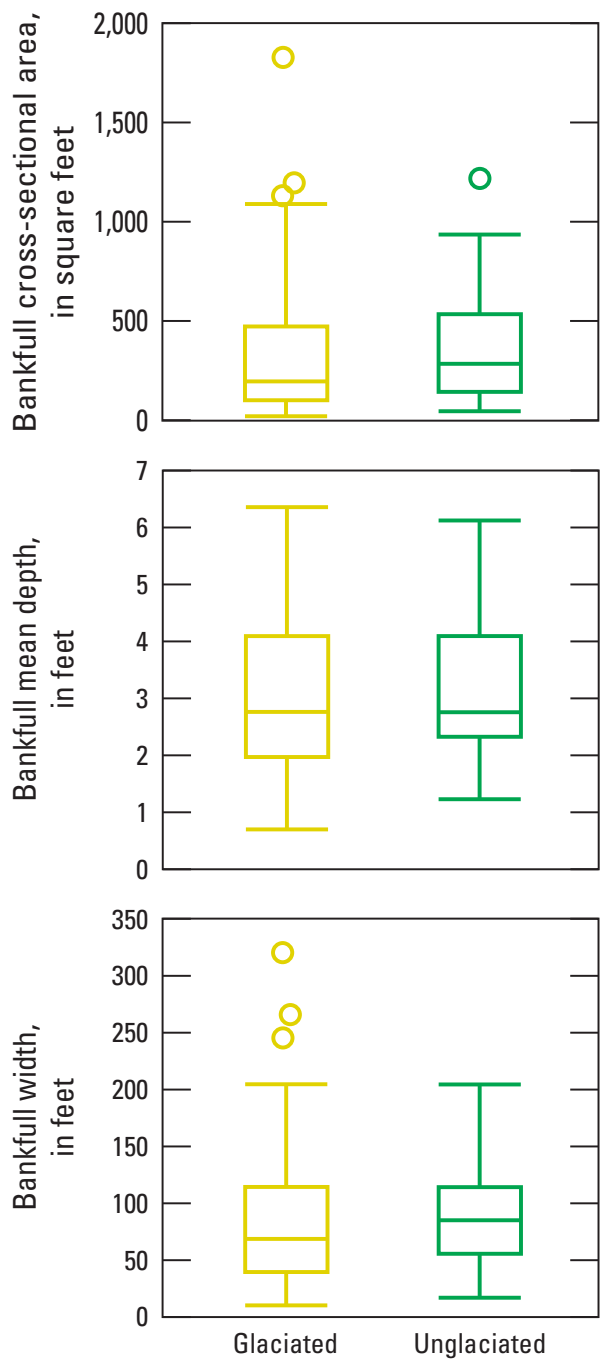

\section{EXPLANATION}

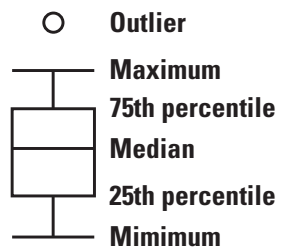

Figure 3. Distribution of sites, drainage area, recurrence interval, bankfull discharge, cross-sectional area, mean depth and width for the glaciated and unglaciated settings of Pennsylvania and southern New York. ( $n$, number of samples) 

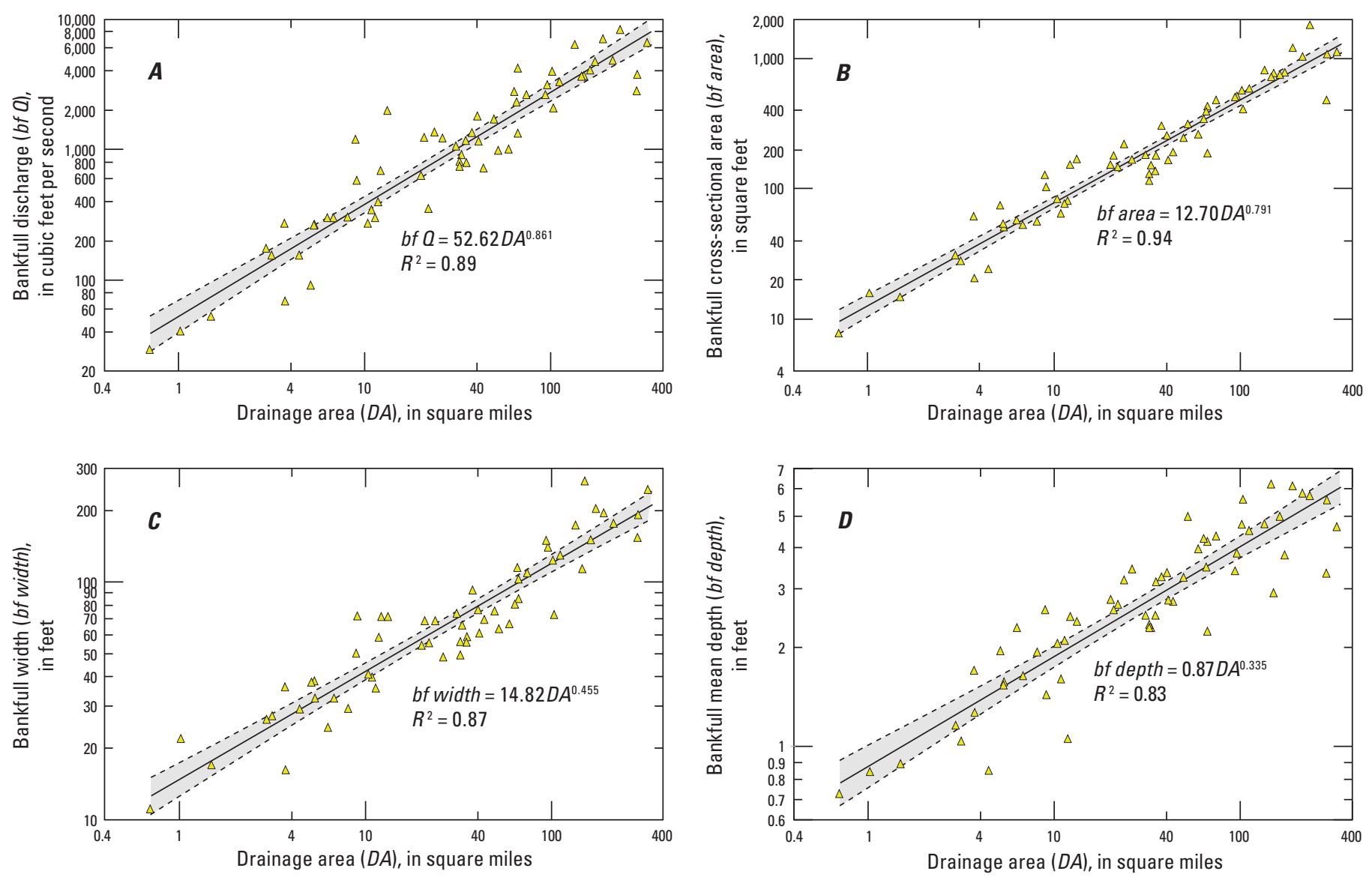

EXPLANATION

95-percent confidence interval
$\Delta \quad$ Glaciated setting

Figure 4. Drainage area in relation to $A$, bankfull discharge, $B$, cross-sectional area, $C$, width, and $D$, mean depth for the glaciated setting of Pennsylvania and southern New York.

natural variability seen in other studies (Doll and others, 2002; Sweet and Geratz, 2003; McCandless, 2003; Lawlor, 2004; Keaton and others, 2005; McCandless and others, 2015). These glaciated relations explain variability slightly better than regional curves developed for the entire noncarbonate region of Pennsylvania (Chaplin, 2005), but further statistical analysis was performed to determine whether or not a data stratification based on glaciation would produce better relations than a combination of all data across settings.

The data for both the glaciated and unglaciated settings included 61 (60.4 percent) and 40 (39.6 percent) sites, respectively (fig. 3). The median and interquartile range of the recurrence interval and mean depth are similar among settings. The median values for the drainage area, bankfull discharge, crosssectional area, and width are lower for the glaciated setting, but the data had a larger range within the group. A comparison of drainage areas in relation to bankfull discharge and channel dimensions for the glaciated and unglaciated setting are shown in figure 5. The results of the ANCOVA for comparison among regression equations for the glaciated and unglaciated settings are shown in table 2. Except for the significantly different intercept of the regional curve relating bankfull discharge to drainage area (table $2, F=8.26, p$-value $<0.005$ ), the equations are not significantly different among the glaciated and unglaciated settings. Therefore, data stratification by glaciation does not further optimize regional curves developed for the noncarbonate (glaciated and unglaciated) and carbonate settings of Pennsylvania and Maryland (Chaplin, 2005). Further analysis that incorporates data stratification or multivariate approaches based on mean annual runoff, precipitation, slope, stream classification, and other relevant parameters may optimize the accuracy and utility of statewide models.

The four new estimates of bankfull discharge and channel dimensions at streamflow- gaging sites in Pennsylvania (table 2, excluding USGS 01525981 in New York) and updated drainage areas from StreamStats (Clune and others, 2018) were incorporated into previous regional curves developed by Chaplin (2005) to produce a set of updated regression 

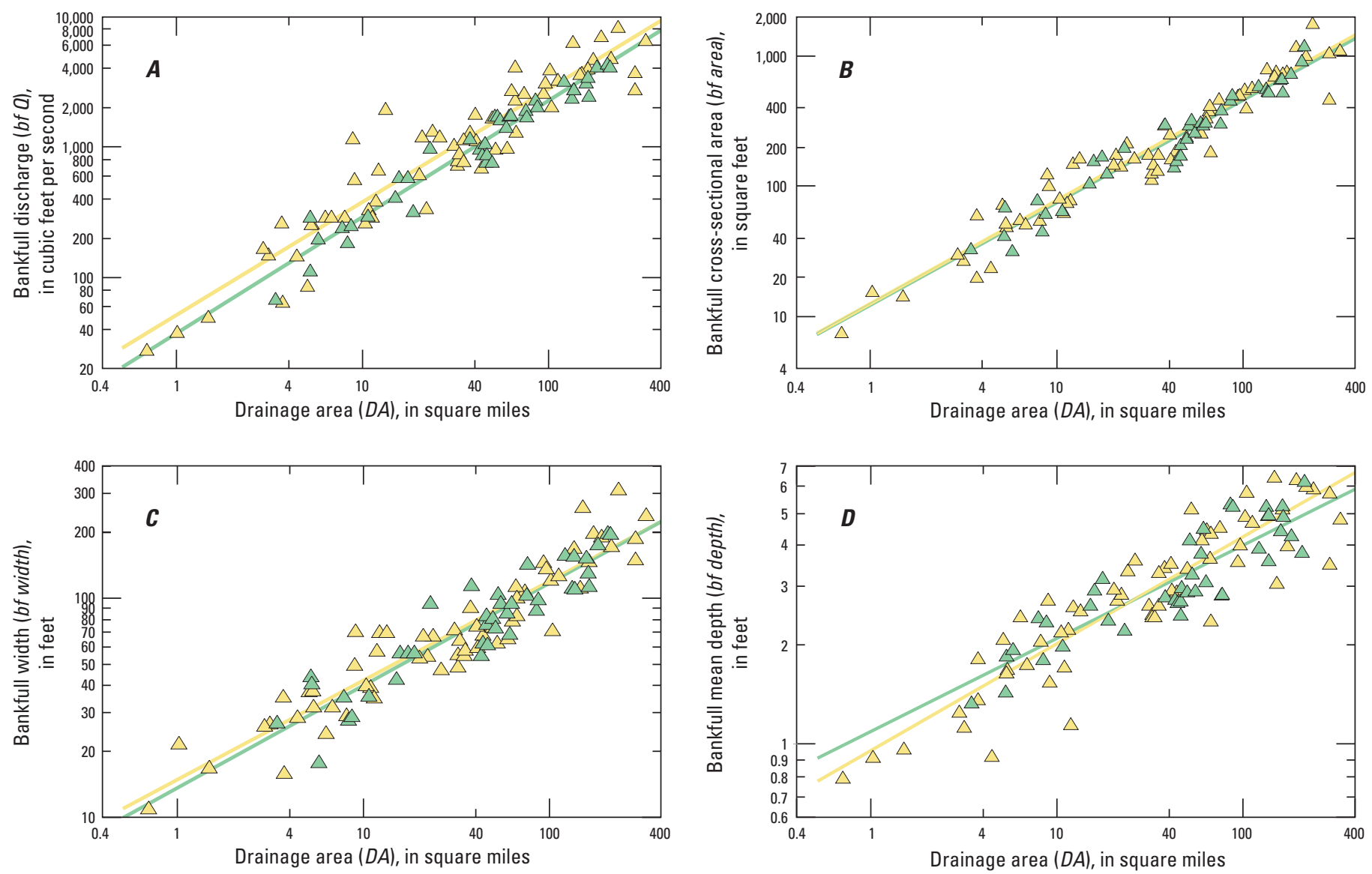

EXPLANATION

$\triangle$ Glaciated setting

$\triangle$ Unglaciated setting

Figure 5. Drainage area in relation to $A$, bankfull discharge, $B$, cross-sectional area, $C$, width, and $D$, mean depth for the noncarbonate glaciated (yellow) and unglaciated (green) settings of Pennsylvania and southern New York.

Table 2. Results of analysis of covariance (ANCOVA) test for differences in slope and intercept among glaciated and unglaciated noncarbonate settings of Pennsylvania and New York.

$[<$, less than $]$

\begin{tabular}{lcccccc}
\hline \multirow{2}{*}{ Covariate } & \multicolumn{2}{c}{ Slope } & & \multicolumn{2}{c}{ Intercept } \\
\cline { 2 - 3 } \cline { 6 - 7 } & $\boldsymbol{F}_{[1,97]}$ & $\boldsymbol{p}$-value & & $\boldsymbol{F}_{[1,98]}$ & $\boldsymbol{p}$-value \\
\hline Bankfull discharge & 0.16 & 0.69 & & 8.26 & $<0.005$ \\
Bankfull cross sectional area & 0.02 & 0.89 & & 0.62 & 0.43 \\
Bankfull width & 0.13 & 0.72 & & 0.46 & 0.50 \\
Bankfull mean depth & 1.51 & 0.22 & & 0.16 & 0.69 \\
\hline
\end{tabular}

relations of bankfull discharge and channel geometry for the noncarbonate and carbonate settings of Pennsylvania and Maryland (fig. 6). The use of previous drainage areas from the National Water Information System (NWIS) was avoided because watershed delineations were often subject to the accuracy of the topographic and positional features from USGS 1:24,000 topographic map series (U.S. Geological Survey, 2012). Additionally, the previous carbonate regional curves were found to be disproportionately influenced by the smallest watershed (Sucker Run near Coatesville, PA, USGS 01480610) and the updated StreamStats analysis has shown that this site is better represented by the noncarbonate setting (the watershed underlain by 30 percent or less carbonate rock). The revised regional curves for the carbonate setting have larger confidence intervals compared to those for the noncarbonate setting. Possible explanations for this difference include the small number of carbonate watersheds in the dataset $(n=10)$, the lack of any explanatory variables for karst 

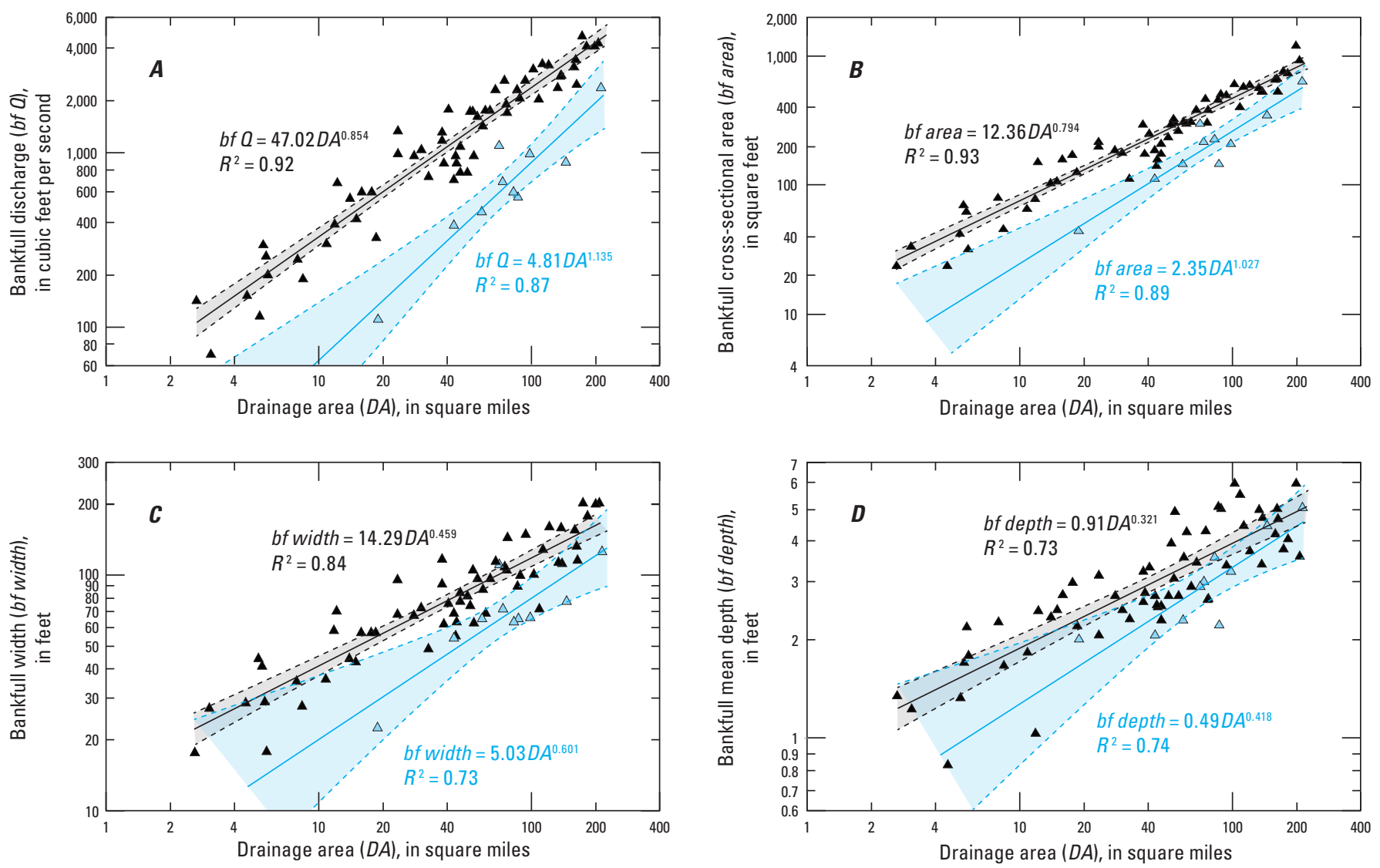

EXPLANATION

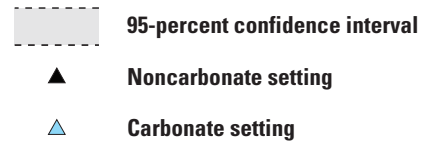

Figure 6. Drainage area in relation to $A$, bankfull discharge, $B$, cross-sectional area, $C$, width, and $D$, mean depth for the noncarbonate (black) and carbonate (blue) settings for streams in Pennsylvania and selected areas of Maryland.

features in the drainage-area model, and the availability of few watersheds of less than $40 \mathrm{mi}^{2}$. Additional bankfull discharge and channel geometry data, particularly from small watersheds in the carbonate setting, would improve regional curve relations for Pennsylvania.

\section{Limitations}

Regional curves are best used as an initial estimate of bankfull parameters and not a substitute for field identification of bankfull and other techniques used for stream restoration design (White, 2001). Increasing the number of sites and the range of drainage areas would strengthen regional curve relations, but the analysis is limited by the availability of streamflow-gaging stations with an adequate period of record. The filter criteria used in this study creates limitations, as it excluded watersheds with greater than 20 percent land use alteration (coal mining, urban development) and flow regulation (dams, and so forth) (Schueler, 1994). Urbanization of even less than 20 percent has been shown to increase discharge amounts and frequency that can change the relation of channel dimensions with the surrounding drainage area. Site specific factors such as beaver dam activity and water withdrawals may also affect flow regulation.

The new (2016) streamflow-gaging stations selected for this study are assumed to not have been significantly altered by flood events. Surveyed stream reaches are often located near bridges that constrict stormflow and produce artificial scouring and filling of the stream's bedload, which can introduce increased variability of estimates. Cross-sectional channel dimensions can vary along stream reaches and the mean values of bankfull area, width, and depth should be used as a guide and not a substitute for site specific field assessment and verification. The regression relations for bankfull discharge and channel dimensions are only applicable to the range of drainage areas used for this study. Extrapolated regions for smaller drainage areas (less than $18 \mathrm{mi}^{2}$ ) are presented in the 
regression relations for the carbonate setting of Pennsylvania based on a linear assumption of relation and is limited by the confidence intervals shown in figure 6.

Low geomorphic topographic reference points such as the active channel or depositional bars were observed consistently at the five newly (2016) surveyed sites in the glaciated settings of Pennsylvania and southern New York, and at numerous sites during previous assessments (fig. 7). These features are shaped at a frequency less than the bankfull discharge recurrence interval and have been used to develop relations among streamflow and channel geometry (Hedman and Osterkamp, 1982). Glacial outwash streams transport a large amount of sediment and the depositional point bars can be distinct features, but are generally topographically lower than bankfull features (D.L. Rosgen, Wildland Hydrology, written commun., 2017). Discretion should be used by stream restoration practitioners especially in glacial outwash streams, because these low depositional features can often be mistaken for bankfull.

Simple linear regression of drainage area versus bankfull discharge and channel dimensions does not include all the possible explanatory parameters (precipitation, runoff, and so forth) that may help reduce variability of the models. The glaciated setting in particular is highly variable based on the amount of outwash materials. The ANCOVA statistical analysis provides further understanding of the geomorphology in a glaciated setting, but does not replace the statewide regional curves previously published for Pennsylvania and the hydroregions of New York (Chaplin, 2005; Mulvihill and others, 2009) or the updated statewide regional curves for Pennsylvania presented in figure 6 .

\section{Summary and Conclusions}

Streambank erosion in areas of past glacial deposition has been shown to be a dominant source of sediment to streams. A geomorphic dataset of the new $(2016, n=5)$ and previous (1999-2006, $n=96)$ estimates of bankfull discharge and channel dimensions at USGS streamflow- gaging stations was compiled to present and contrast the noncarbonate glaciated and unglaciated settings of Pennsylvania and southern New York. Empirical models were developed using simple linear regressions that relate bankfull discharge and channel geometry to drainage area (regional curves). Significant relations $(p$-value $<0.005)$ were able to explain variability with coefficients of determination $\left(R^{2}\right)$ of 0.89 for bankfull discharge, 0.94 for cross-sectional area, 0.87 for bankfull width, and 0.83 for bankfull depth. These regression relations were able to provide a slightly better fit than regional curve models developed for the entire noncarbonate region of Pennsylvania.

The results of the ANCOVA analysis comparing regression equations for the glaciated and unglaciated setting indicate that except for the significant intercept of bankfull discharge versus drainage area $(F=8.26, p<0.05)$, the equations are not significantly different among the settings. Therefore, data stratification by glaciation does not improve regional curves relations developed previously for the noncarbonate (glaciated and unglaciated) and carbonate settings of Pennsylvania and Maryland. Further analysis that incorporates data stratification or multivariate approaches based on mean annual runoff, precipitation, slope, stream classification, or other relevant parameters may optimize the accuracy and utility of

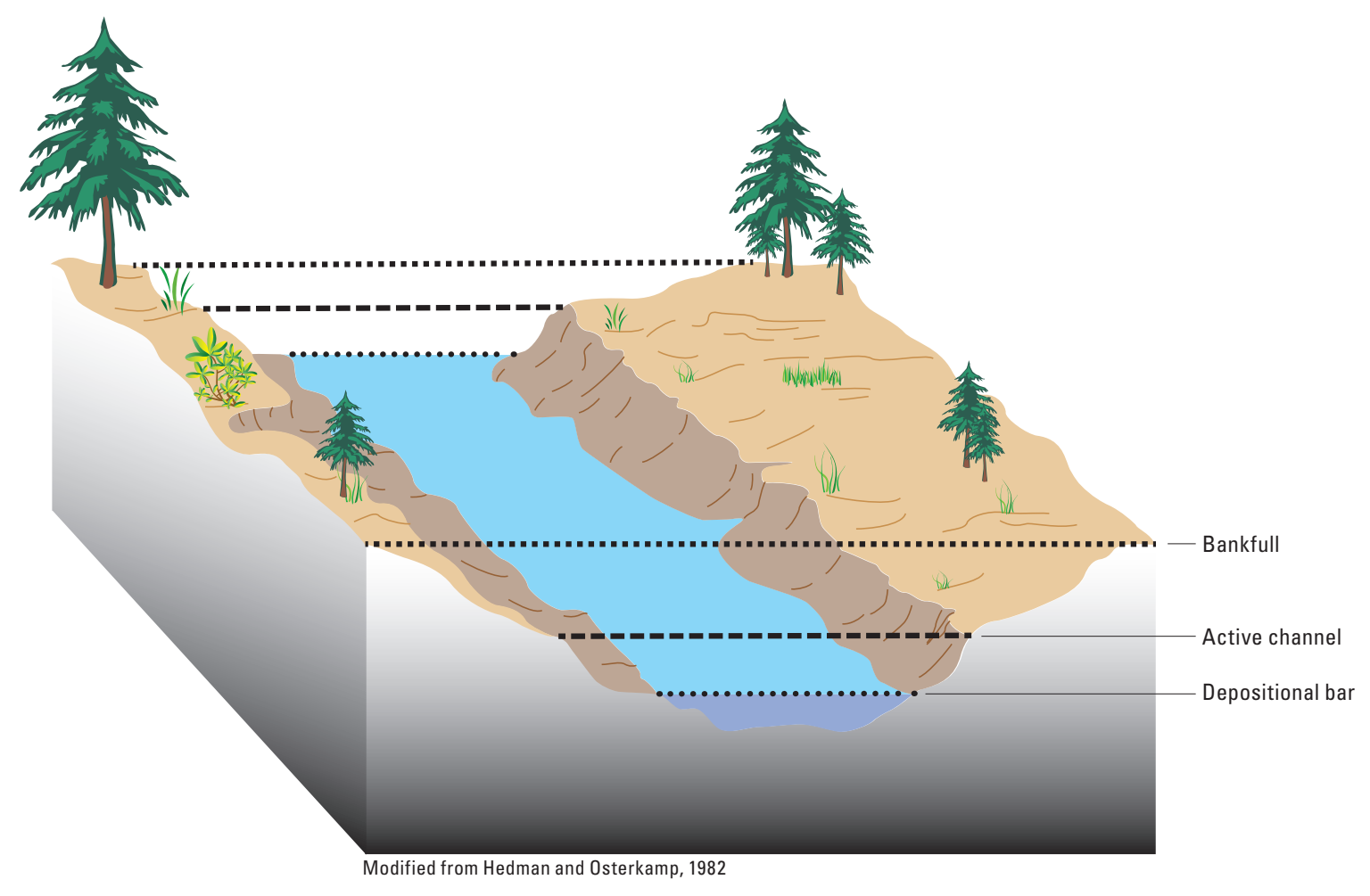

Figure 7. Geomorphic reference points of bankfull, active-channel, and depositional bar. 
statewide models. The new estimates of bankfull discharge and channel dimensions at streamflow-gaging sites and revised drainage areas from StreamStats were incorporated into previously developed regional curves to produce updated regression relations of bankfull discharge and channel geometry for the noncarbonate and carbonate settings of Pennsylvania and Maryland.

As streamflow-gaging stations with an adequate period of record become available overtime, this would increase the number of sites and the range of drainage areas that would further strengthen regional curve relations. This report provides an evaluation of the most reliable model estimates and predictions of bankfull discharge and channel geometry to aid classification, monitoring and restoration efforts of streams in the glaciated settings of Pennsylvania. Regional curves are best used as an initial estimate of bankfull parameters and not as a substitute for field identification of bankfull and other techniques used for stream restoration design.

\section{References Cited}

Ashmore, P., 1993, Contemporary erosion of the Canadian landscape: Progress in Physical Geography, v. 17, no. 2, p. 190-204.

Bain, D.J., Green, M.B., Campbell, J.L., Chamblee, J.F., Chaoka, S., Fraterrigo, J.M., Kaushal, S.S., Martin, S.L., Jordan, T.E., Parolari, A.J., Sobczak, W.V., Weller, D.E., Wollheim, W.M., Boose, E.R., Duncan, J.M., Gettle, G.M., Hall, B.R., Kumar, P., Thompson, J.R., Vose, J.M., Elliott, E.M., and Leigh, D.S., 2012, Legacy effects in material flux-Structural catchment changes predate long-term studies: BioScience, v. 62, no. 6, p. 575-584.

Bradford County Conservation District, 2013, Bradford County Stream Maintenance Pilot: Training manual, 37 p.

Bernard, J.M., Fripp, J., and Robinson, K., 2007, National engineering handbook-Stream restoration design: U.S. Department of Agriculture, Natural Resources Conservation Service, 210-VI-NEH, part 654, accessed November 2017, at https://www.nrcs.usda.gov/wps/portal/nrcs/detail/ national/water/manage/restoration/?cid=stelprdb1044707.

Bernhardt, E.S., 2005, Synthesizing U.S. river restoration efforts: Science, v. 308, no. 5722, p. 636-637.

Brakebill, J.W., Ator, S.W., and Schwarz, G.E., 2010, Sources of suspended-sediment flux in streams of the Chesapeake Bay watershed-A regional application of the SPARROW model: Journal of the American Water Resources Association, v. 46, no. 4, p. 757-776.
Chaplin, J.J., 2005, Development of regional curves relating bankfull-channel geometry and discharge to drainage area for streams in Pennsylvania and selected areas of Maryland: U.S. Geological Survey Scientific Investigations Report 2005-5147, 34 p., accessed November 15, 2017, at https:// pubs.usgs.gov/sir/2005/5147/SIR2005-5147.pdf.

Cinotto, P.J., 2003, Development of regional curves of bankfull-channel geometry and discharge for streams in the nonurban, Piedmont Physiographic Province, Pennsylvania and Maryland: U.S. Geological Survey Water-Resources Investigations Report 2003-4014, 27 p., accessed November 15, 2017, at https://pubs.er.usgs.gov/publication/wri034014.

Clune, J.W., Chaplin, J.J. and White, K.E., 2018, Elevation and pebble count data for 5 new sites in the glaciated setting of Pennsylvania and southern New York and StreamStats drainage areas for 70 sites in Pennsylvania: U.S. Geological Survey data release, https://doi.org/10.5066/P963SDEY.

Clune, J.W., Gellis, A.C., and McKee, L., 2010, Agricultural soil erosion rates for the Linganore Creek Watershed in the Piedmont Physiographic Province of the Chesapeake Bay watershed, in Hydrology and sedimentation for a changing future-Existing and emerging issues, 2nd, Joint Federal Interagency Conference, June 27-July 1, Las Vegas, NV, $8 \mathrm{p}$. [Also available at https://acwi.gov/sos/pubs/2ndJFIC/ Contents/7A3_Clune_03_10_2010_paper.pdf.]

Dearmont, D., McCarl, B.A., and Tolman, D.A., 1998, Costs of water treatment due to diminished water quality-A case study in Texas: Water Resources Research, v. 34, no. 4, p. $849-853$.

Doll, B.A., Wise-Frederick, D.E., Buckner, C.M., Wilkerson, S.D., Harman, W.A., Smith, R.E., and Spooner, J., 2002, Hydraulic geometry relationships for urban streams throughout the Piedmont of North Carolina: Journal of the American Water Resources Association, v. 38, no. 3, p. 641-651.

Dunne, T., and Leopold, L.B., 1978, Water in environmental planning: San Francisco, W.H. Freeman, 818 p.

Federal Interagency Stream Restoration Working Group, 1998, Stream corridor restoration-Principles, processes, and practices: Federal Interagency Stream Restoration Working Group, 637 p., accessed November 2017, at https:// www.nrcs.usda.gov/Internet/FSE_DOCUMENTS/stelprdb1044574.pdf.

Fox, J., and Weisberg, S., 2011, An R companion to applied regression $(2 \mathrm{~d}$ ed.): Thousand Oaks, California, Sage Publications, 472 p., accessed November 2017, at http://socserv. socsci.mcmaster.ca/jfox/Books/Companion. 
Gellis, A.C., Banks, W.S.L., Langland, M.J., and Martucci, S.K., 2004, Summary of suspended-sediment data for streams draining the Chesapeake Bay Watershed, water years 1952-2002: U.S. Geological Survey Scientific Investigations Report 2004-5056, 59 p.

Gellis, A.C., Hupp, C.R., Pavich, M.J., Landwehr, J.M., Banks, W.S.L., Hubbard, B.E., Langland, M.J., Ritchie, J.C., and Reuter, J.M., 2009, Sources, transport, and storage of sediment at selected sites in the Chesapeake Bay watershed: U.S. Geological Survey Scientific Investigations Report 2008-5186, 97 p.

Gellis, A.C., Noe, G.B., Clune, J.W., Myers, M.K., Hupp, C.R., Schenk, E.R., and Schwarz, G.E., 2015, Sources of fine-grained sediment in the Linganore Creek watershed, Frederick and Carroll Counties, Maryland, 2008-10: U.S. Geological Survey Scientific Investigations Report 2014 5147, 56 p., accessed November 2017, at http://dx.doi. org/10.3133/sir20145147.

Gordon, R.B., 1979, Denudation rate of central New England determined from estuarine sedimentation: American Journal of Science, v. 279, no. 6, p. 632-642.

Harrelson, C.C., Rawlins, C.L., and Potyondy, J.P., 1994, Stream channel reference sites-An illustrated guide to field technique: U.S. Department of Agriculture, Forest Service, General Technical Report RM-245, 62 p.

Hedman, E.R., and Osterkamp, W.R., 1982, Streamflow characteristics related to channel geometry of streams in western United States: U.S. Geological Survey Water -Supply Paper 2193, 17 p., accessed November 2017, at http://pubs.er.usgs. gov/publication/wsp2193.

Helsel, D.R., and Hirsch, R.M., 2002, Statistical methods in water resources: U.S. Geological Survey Techniques of Water-Resources Investigations, book 4, chap. A3, 522 p.

Henley, W., Patterson, M., Neves, R., and Lemly, A.D., 2000, Effects of sedimentation and turbidity on lotic food websA concise review for natural resource managers: Reviews in Fisheries Science, v. 8, no. 2, p. 125-139.

James, L.A., 2013, Legacy sediment—Definitions and processes of episodically produced anthropogenic sediment: Anthropocene, v. 2, p. 16-26.

Keaton, J.N., Messinger, T., and Doheny, E.J., 2005, Development and analysis of regional curves for streams in the non-urban Valley and Ridge physiographic province, Maryland, Virginia, and West Virginia: U.S. Geological Survey Scientific Investigations Report 2005-5076, 109 p., accessed November 17, 2017, at https://pubs.usgs.gov/ $\operatorname{sir} / 2005 / 5076 /$.
Langland, M.J., 2015, Sediment transport and capacity change in three reservoirs, Lower Susquehanna River Basin, Pennsylvania and Maryland, 1900-2012: U.S. Geological Survey Open-File Report 2014-1235, 18 p., accessed on November 2017, at http://dx.doi.org/10.3133/ofr20141235.

Lawlor, S.M., 2004, Determination of channel-morphology characteristics, bankfull discharge, and various design-peak discharges in western Montana: U.S. Geological Survey Scientific Investigations Report 2004-5263, 19 p., accessed November 17, 2017, at https://pubs.usgs.gov/sir/2004/5263/ pdf/sir_2004_5263.pdf.

Leopold, L.B., 1992, Sediment size that determines channel morphology, in Billi, P., Hey, R.D., Thorne, C.R., and Tacconi, P., eds., Dynamics of gravel-bed rivers: Chichester, U.K., John Wiley \& Sons, p. 297-311.

Leopold, L.B., and Maddock, T., 1953, The hydraulic geometry of stream channels and some physiographic implications: U.S. Geological Survey Professional Paper 252, 56 p.

Leopold, L.B., Wolman, M.G., and Miller, J.P., 1964, Fluvial processes in geomorphology: San Francisco, Freeman, $522 \mathrm{p}$.

Lumia, R., 1991, Regionalization of flood discharges for rural, unregulated streams in New York, excluding Long Island: U.S. Geological Survey Water-Resources Investigations Report 90-4197, 119 p., accessed November 17, 2017, at https://pubs.usgs.gov/wri/1990/4197/report.pdf.

McCandless, T.L., 2003, Maryland stream survey—Bankfull discharge and channel characteristics of streams in the Coastal Plain hydrologic region: U.S. Fish and Wildlife Service, Chesapeake Bay Field Office, CBFO-S03-02, 29 p.

McCandless, T.L., Starr, R.R., and Harman, W.A., 2015, Bankfull regional curves for the Alleghany Plateau/Valley and Ridge, Piedmont, and Coastal Plain regions of Maryland: Journal of the American Water Resources Association, v. 51 , no. 6 , p. $1568-1580$.

Miller, H.M., 1986, Transforming a "Splendid and delightsome land"-Colonists and ecological change in the Chesapeake 1607-1820: Journal of the Washington Academy of Sciences, v. 76 , p. 173-187.

Miller, S.J., and Davis, D., 2003, Identifying and optimizing regional relationships for bankfull discharge and hydraulic geometry at USGS stream gage sites in the Catskill Mountains, NY: New York City Department of Environmental Protection Technical Report, $10 \mathrm{p}$.

Müller-Schwarze, D., and Sun, L., 2003, The beaver-Natural history of a wetlands engineer: Ithaca, N.Y, Cornell University Press, $190 \mathrm{p}$. 
Mulvihill, C.I., and Baldigo, B.P., 2007, Regionalized equations for bankfull-discharge and channel characteristics of streams in New York State-Hydrologic Region 3 east of the Hudson River: U.S. Geological Survey Scientific Investigations Report 2007-5227, 15 p., accessed November 2017, at http://pubs.er.usgs.gov/publication/sir20075227.

Mulvihill, C.I., and Baldigo, B.P., 2012, Optimizing bankfull discharge and hydraulic geometry relations for streams in New York State: Journal of the American Water Resources Association, v. 48, no. 3, p. 449-463.

Mulvihill, C.I., Baldigo, B.P., Miller, S.J., DeKoskie, D., and DuBois, J., 2009, Bankfull discharge and channel characteristics of streams in New York State: U.S. Geological Survey Scientific Investigations Report 2009-5144, 52 p., accessed November 2017, at http://pubs.er.usgs.gov/publication/ sir20095144.

Mulvihill, C.I., Ernst, A.G., and Baldigo, B.P., 2005, Regionalized equations for bankfull-discharge and channel characteristics of streams in New York State-Hydrologic Region 6 in the Southern Tier of New York: U.S. Geological Survey Scientific Investigations Report 2005-5100, 14 p., accessed November 2017, at http://pubs.er.usgs.gov/publication/ $\operatorname{sir} 20055100$.

Mulvihill, C.I., Filopowicz, A., Coleman, A., and Baldigo, B.P., 2007, Regionalized equations for bankfull discharge and channel characteristics of streams in New York StateHydrologic regions 1 and 2 in the Adirondack Region of northern New York: U.S. Geological Survey Scientific Investigations Report 2007-5189, 19 p., accessed November 2017, at http:/pubs.er.usgs.gov/publication/ sir20075189.

Nagle, G.N., Fahey, T.J., Ritchie, J.C., and Woodbury, P.B., 2007, Variations in sediment sources and yields in the Finger Lakes and Catskills regions of New York: Hydrological Processes, v. 21, no. 6, p. 828-838.

Naiman, R.J., Johnston, C.A., and Kelley, J.C., 1988, Alteration of North American streams by beaver: BioScience, v. 38, no. 11, p. 753-762.

R Core Team, 2017, R-A language and environment for statistical computing: R Foundation for Statistical Computing, Vienna, Austria, accessed November 2017, at http:// www.R-project.org/.

Ries, K.G., III, Guthrie, J.G., Rea, A.H., Steeves, P.A., and Stewart, D.W., 2008, StreamStats-A water resources web application: U.S. Geological Survey Fact Sheet 2008-3067, 6 p., accessed November 2017, at https://pubs.usgs.gov/ fs/2008/3067/pdf/fs-2008-3067-508.pdf.
Ries, K.G., III, Steeves, P.A., Coles, J.D., Rea, A.H., and Stewart, D.W., 2004, StreamStats-A U.S. Geological Survey web application for stream information: U.S. Geological Survey Fact Sheet 2004-3115, 4 p., accessed November 2017, at http://pubs.er.usgs.gov/publication/fs20043115.

Rosgen, D.L., 1994, A classification of natural rivers: Catena, v. 22 , no. 3, p. 169-199.

Rosgen, D.L., 1996, Applied river morphology: Pagosa Springs, Colorado, Wildland Hydrology, Inc., 378 p.

Rosgen, D.L., 1997, A geomorphological approach to restoration of incised rivers, in Wang, S.S.Y., Langendoen, E.J., and Shields, F.D., Jr., eds., Proceedings of the conference on management of landscapes disturbed by channel incision: Oxford, Mississippi, The Center for Computational Hydroscience and Engineering, May 19-23, 11 p.

Schueler, T.R., 1994, The importance of imperviousness: Watershed Protection Techniques, v. 1, no. 3, p. 100-111.

Sekely, A.C., Mulla, D., and Bauer, D., 2002, Streambank slumping and its contribution to the phosphorus and suspended sediment loads of the Blue Earth River, Minnesota: Journal of Soil and Water Conservation, v. 57, no. 5, p. 243-250.

Shultz, C.H., ed., 1999, The geology of Pennsylvania: Pennsylvania Geological Survey and Pittsburgh Geological Society, Harrisburg, Pa., 888 p.

Somerville, D.E., 2010, Stream assessment and mitigation protocols - A review of commonalities and differencesAppendix A, Hydraulic regional curves for selected areas of the United States: Prepared for the U.S. Environmental Protection Agency, Office of Wetlands, Oceans, and Watersheds, EPA 843-S-12-003, 10 p.

Sweet, W.V., and Geratz, J.W., 2003, Bankfull hydraulic geometry relationships and recurrence intervals for North Carolina's coastal plain: Journal of the American Water Resources Association, v. 39, no. 4, p. 861-871.

U.S. Department of Agriculture [2017], Regional hydraulic geometry curves: U.S. Department of Agriculture, Natural Resources Conservation Service web page, accessed November 2017, at https://www.nrcs.usda.gov/wps/portal/ $\mathrm{nrcs} /$ detail/national/water/?cid=nrcs143_015052.

U.S. Environmental Protection Agency, 2009, National water quality inventory report to Congress: U.S. Environmental Protection Agency, Office of Water, Washington, D.C., EPA 841-R-08-001, 43 p., accessed November 2017, at https:// www.epa.gov/sites/production/files/2015-09/documents/200 9_01_22_305b_2004report_2004_305breport.pdf. 
U.S. Geological Survey, 1966, Topographic instructions of the U.S. Geological Survey - Leveling: U.S. Geological Survey, book 2, 63 p. [Also available at https://pubs.usgs. gov/unnumbered/70045432/report.pdf.]

U.S. Geological Survey, 2012, Guidance on Determination and Revision of Watershed Drainage Areas: U.S. Geological Survey Office of Surface Water Technical Memorandum 12.07, accessed April 18, 2018, at https:/water.usgs.gov/ $\mathrm{admin} / \mathrm{memo} / \mathrm{SW} / \mathrm{sw} 12.07 . \mathrm{html}$.

U.S. Geological Survey, 2013a, USGS NED n42w077 1 arcsecond 20131 x 1 degree ArcGrid, DEM raster digital data: U.S. Geological Survey National Map, accessed December 1, 2017, at http://nationalmap.gov/viewer.html.

U.S. Geological Survey, 2013b, User's manual for the National Water Information System of the U.S. Geological Survey (ver. 5.1)—Automated Data Processing System (ADAPS): U.S. Geological Survey Open-File Report 03-123, accessed November 2017, at http://nwis.usgs.gov/ currentdocs/adaps/adaps.book.html.

Walter, R.C., and Merritts, D.J., 2008, Natural streams and the legacy of water-powered mills: Science, v. 319, no. 5861, p. 299-304.
Westergard, B.E., Mulvihill, C.I., Ernst, A.G., and Baldigo, B.P., 2005, Regionalized equations for bankfull-discharge and channel characteristics of streams in New York stateHydrologic Region 5 in central New York: U.S. Geological Survey Scientific Investigations Report 2004-5247, 16 p., accessed November 2017, at http://pubs.er.usgs.gov/publication/sir20045247.

White, K.E., 2001, Regional curve development and selection of a reference reach in the non-urban, lowland sections of the piedmont physiographic province, Pennsylvania and Maryland: U.S. Geological Survey Water-Resources Investigations Report 2001-4146, 20 p., accessed November 17, 2017, at https://pubs.er.usgs.gov/publication/wri014146.

Wilkerson, G.V., Kandel, D.R., Perg, L.A., Dietrich, W.E., Wilcock, P.R., and Whiles, M.R., 2014, Continental-scale relationship between bankfull width and drainage area for single-thread alluvial channels: Water Resources Research, v. 50, no. 2, p. 919-936.

Wolman, M.G., 1954, A method of sampling coarse river-bed material: Transactions, American Geophysical Union, v. 35, no. 6, p. 951-956.

Wolman, M.G., and Miller, J.P., 1960, Magnitude and frequency of forces in geomorphic processes: The Journal of Geology, v. 68, no. 1, p. 54-74. 


\section{Appendix 1.}

Photographic documentation, bankfull-channel geometry, and substrate data collected for new (2016) stream locations selected for development of regional curves 


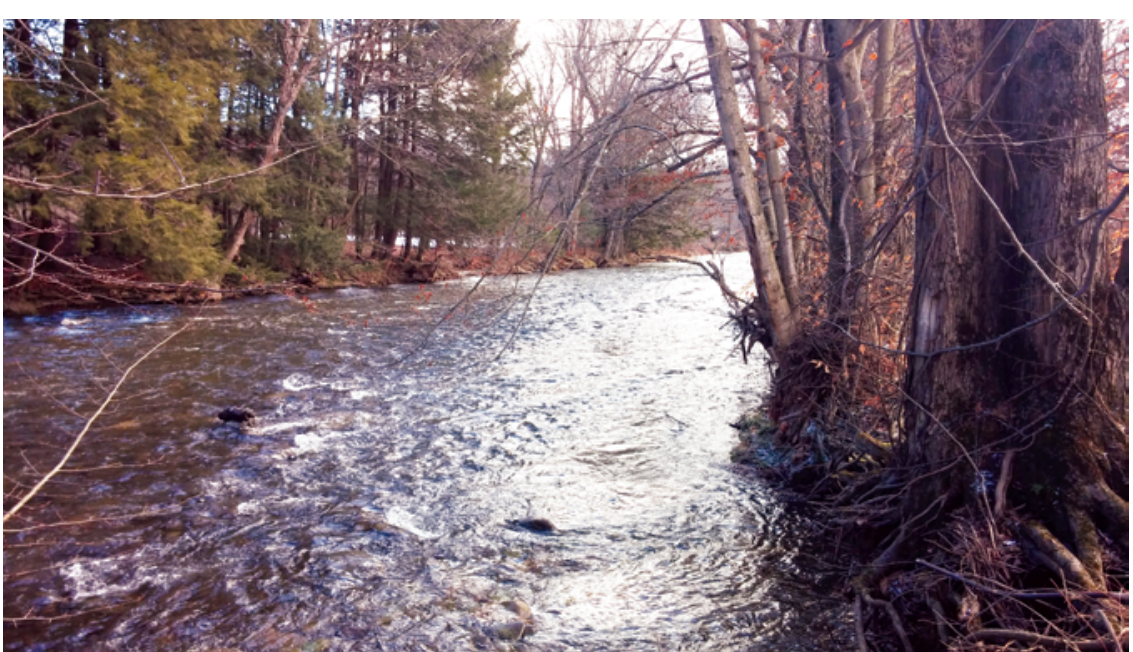

View looking downstream at the reach of West Branch Lackawaxen River at station 133.

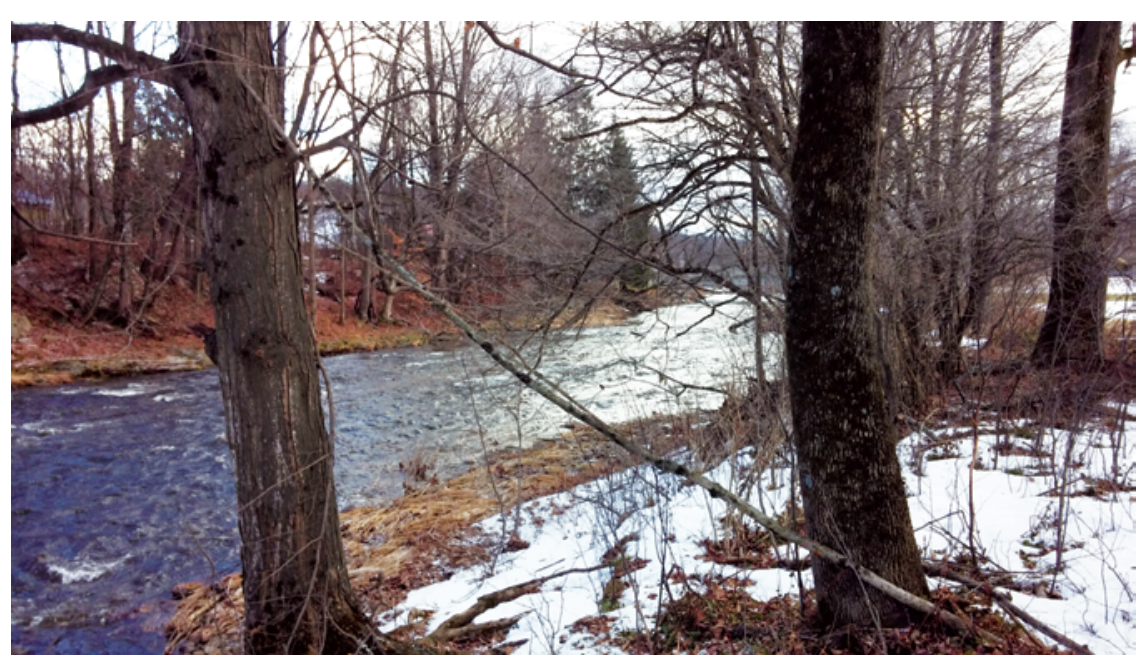

View looking downstream at the reach of West Branch Lackawaxen River at station 860.

\begin{tabular}{lr}
\hline \multicolumn{2}{c}{ Cross-sectional data at station 133 } \\
\hline Bankfull cross-sectional area (square feet) & 243.2 \\
Bankfull width (feet) & 70.5 \\
Bankfull mean depth (feet) & 3.5 \\
D50 (millimeters) & 52.2 \\
D84 (millimeters) & 151.2 \\
\hline
\end{tabular}

\begin{tabular}{lr}
\hline \multicolumn{2}{c}{ Cross-sectional data at station 860 } \\
\hline Bankfull cross-sectional area (square feet) & 269.2 \\
Bankfull width (feet) & 81.2 \\
Bankfull mean depth (feet) & 3.3 \\
D50 (millimeters) & 74.5 \\
D84 (millimeters) & 221.7 \\
\hline
\end{tabular}

U.S. Geological Survey streamflow-gaging station 01428750

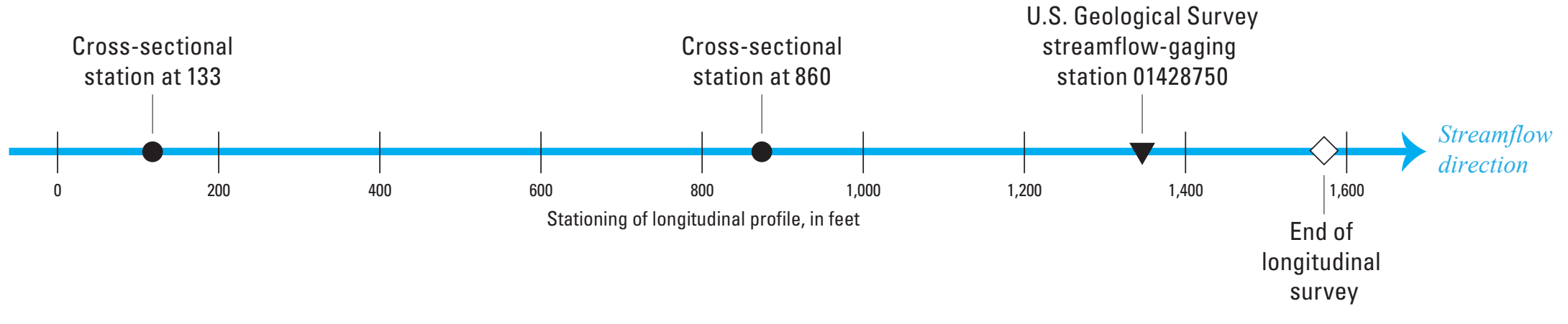




\section{Tuscarora Creek above South Addison, NY (Station number 01525981)}

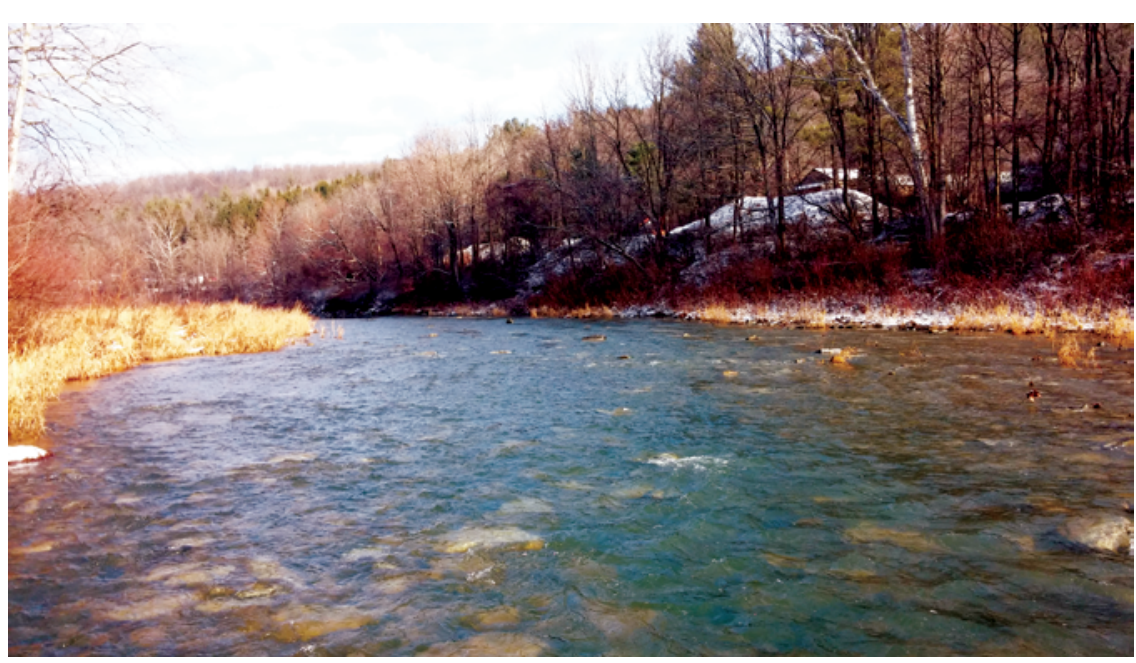

View looking upstream at the reach of Tuscarora Creek at station 230.

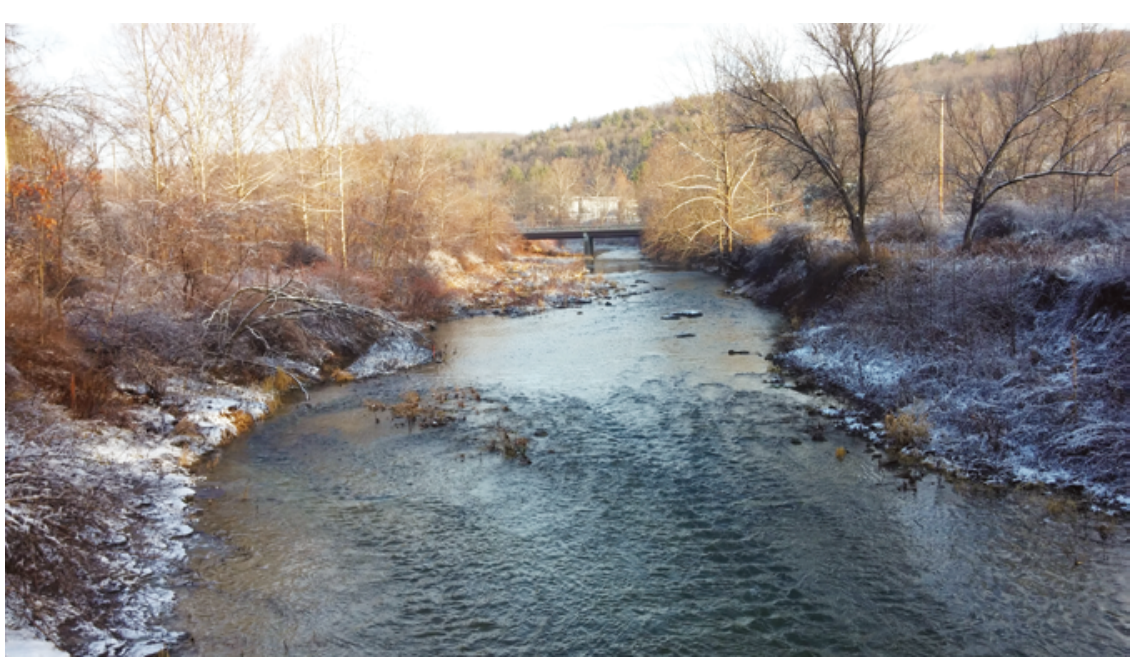

View looking upstream at the reach of Tuscarora Creek at station 1324.

\begin{tabular}{lr}
\hline \multicolumn{2}{c}{ Cross-sectional data at station 230 } \\
\hline Bankfull cross-sectional area (square feet) & 561.0 \\
Bankfull width (feet) & 139.7 \\
Bankfull mean depth (feet) & 4.0 \\
D50 (millimeters) & 71.6 \\
D84 (millimeters) & 188.4 \\
\hline
\end{tabular}

\begin{tabular}{lr}
\hline \multicolumn{2}{c}{ Cross-sectional data at station 1324 } \\
\hline Bankfull cross-sectional area (square feet) & 575.1 \\
Bankfull width (feet) & 105.5 \\
Bankfull mean depth (feet) & 5.5 \\
D50 (millimeters) & 78.4 \\
D84 (millimeters) & 207.3 \\
\hline
\end{tabular}

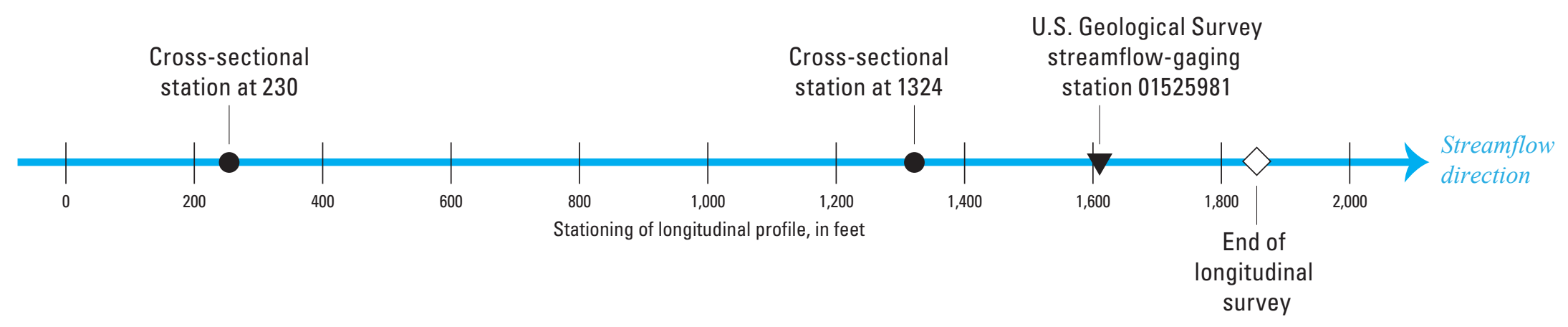




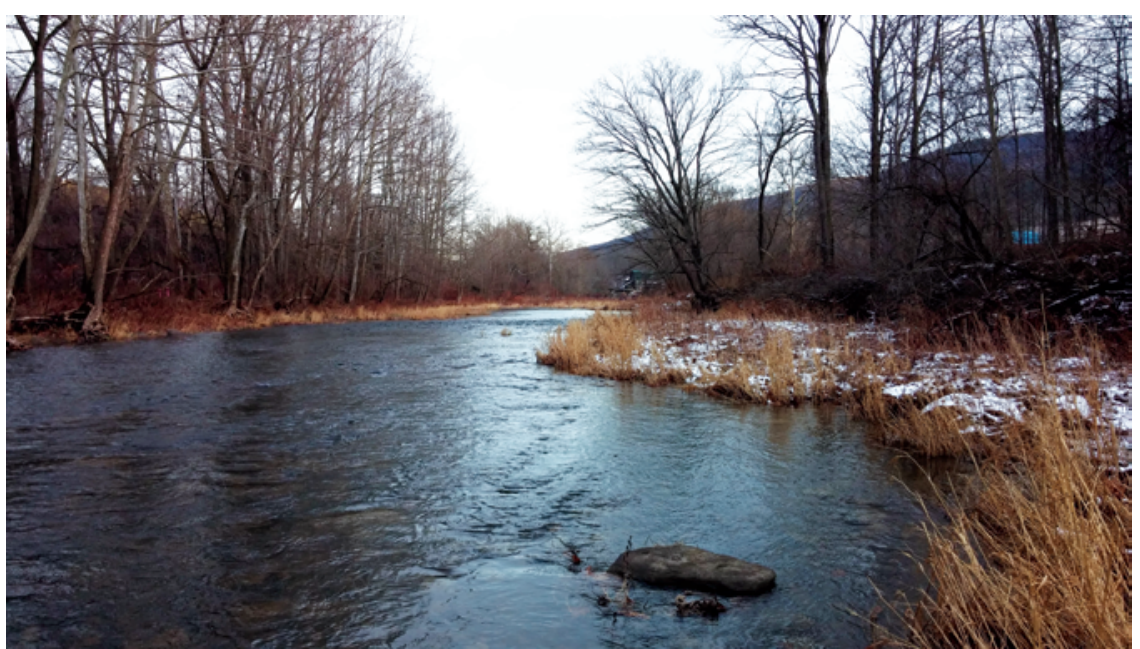

View looking downstream at the reach of Towanda Creek at station 136.

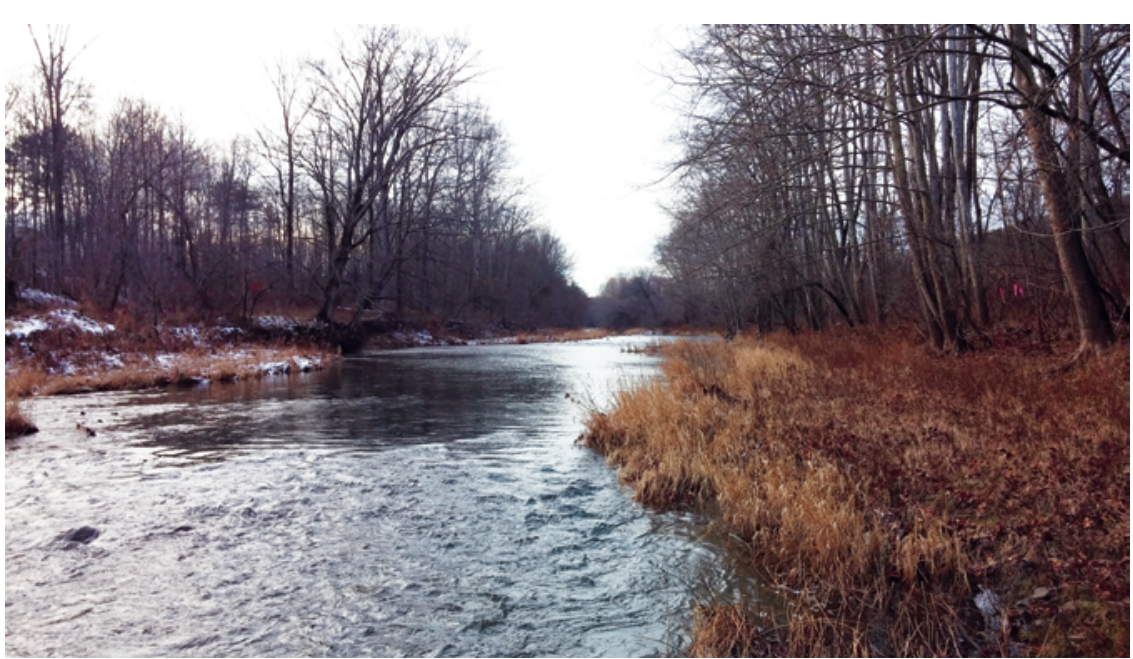

View looking upstream at the reach of Towanda Creek at station 463.

\begin{tabular}{lr}
\hline \multicolumn{2}{c}{ Cross-sectional data at station 136 } \\
\hline Bankfull cross-sectional area (square feet) & 624.1 \\
Bankfull width (feet) & 131.0 \\
Bankfull mean depth (feet) & 4.8 \\
D50 (millimeters) & 137.3 \\
D84 (millimeters) & 235.2 \\
\hline
\end{tabular}

\begin{tabular}{lr}
\hline \multicolumn{2}{c}{ Cross-sectional data at station 463 } \\
\hline Bankfull cross-sectional area (square feet) & 547.1 \\
Bankfull width (feet) & 127.0 \\
Bankfull mean depth (feet) & 4.3 \\
D50 (millimeters) & 80.4 \\
D84 (millimeters) & 232.0 \\
\hline
\end{tabular}

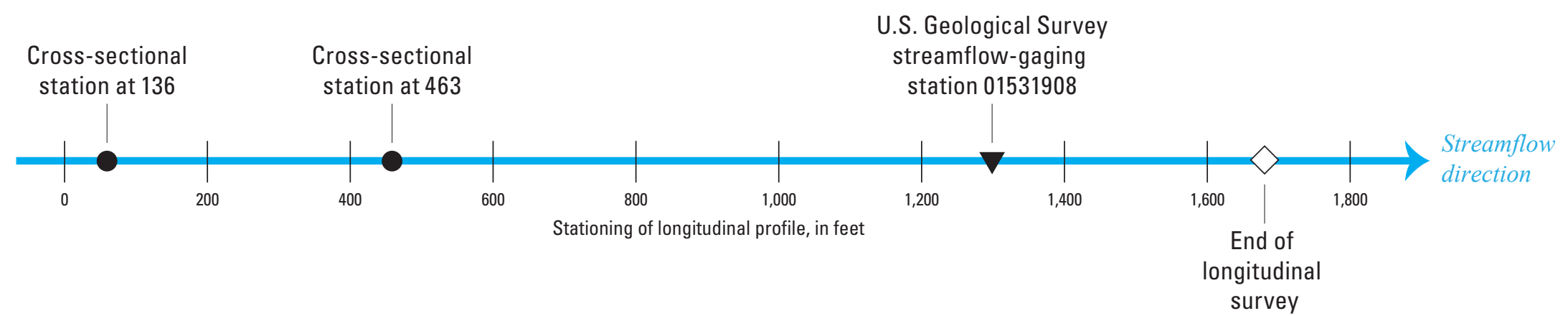

U.S. Geological Survey treamflow-gaging station 01531908 


\section{Sugar Creek at West Burlington, PA (Station number 01531325)}

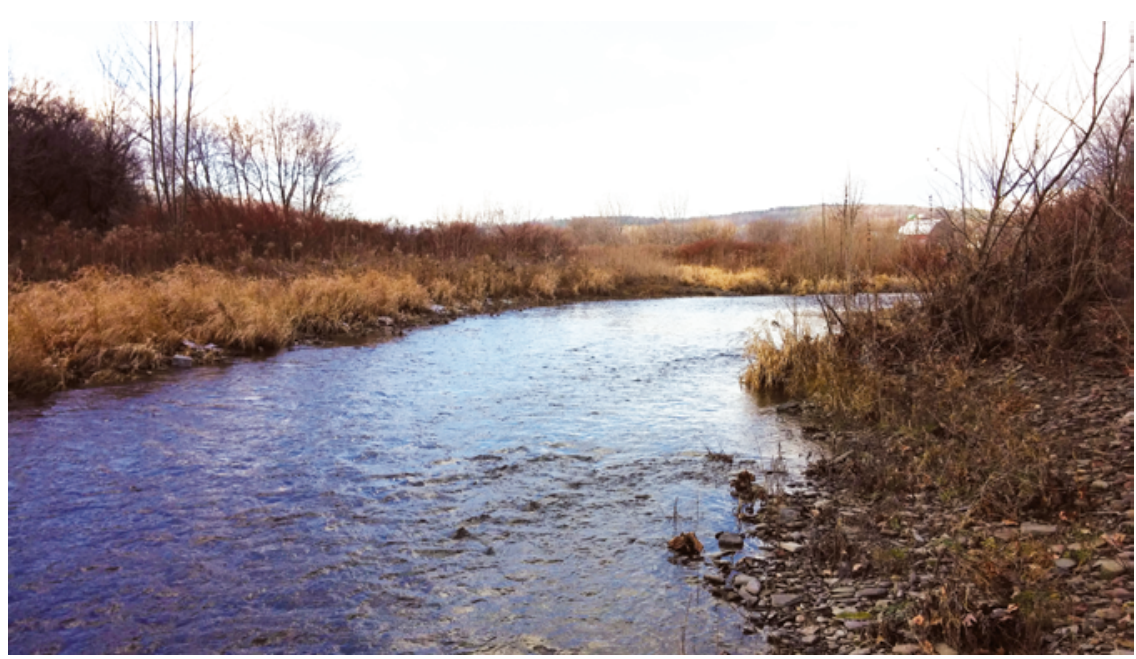

View looking upstream at the reach of Sugar Creek at station 21.

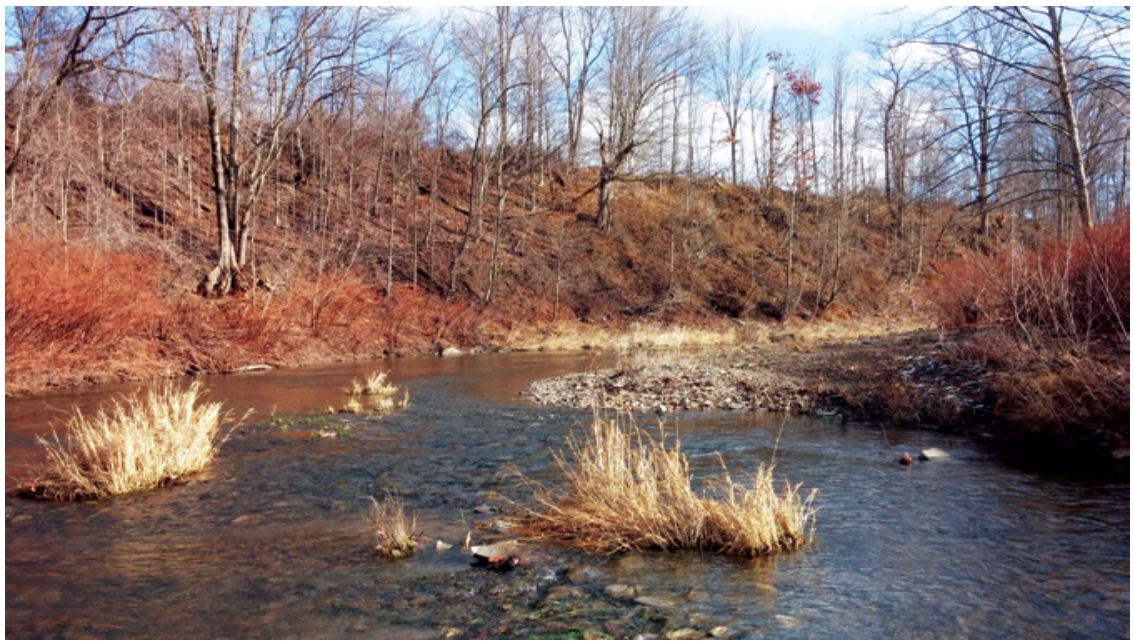

View looking downstream at the reach of Sugar Creek at station 527.

\begin{tabular}{lr}
\hline \multicolumn{2}{c}{ Cross-sectional data at station 21 } \\
\hline Bankfull cross-sectional area (square feet) & 541.7 \\
Bankfull width (feet) & 168.0 \\
Bankfull mean depth (feet) & 3.2 \\
D50 (millimeters) & 41.9 \\
D84 (millimeters) & 146.7 \\
\hline
\end{tabular}

\begin{tabular}{lr}
\hline \multicolumn{2}{c}{ Cross-sectional data at station 527 } \\
\hline Bankfull cross-sectional area (square feet) & 467.8 \\
Bankfull width (feet) & 129.5 \\
Bankfull mean depth (feet) & 3.6 \\
D50 (millimeters) & 48.0 \\
D84 (millimeters) & 179.5 \\
\hline
\end{tabular}

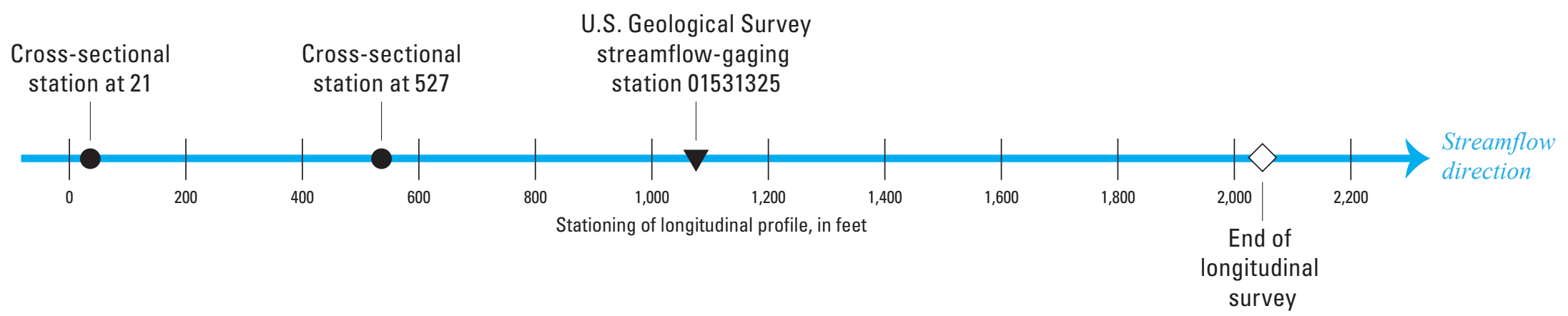




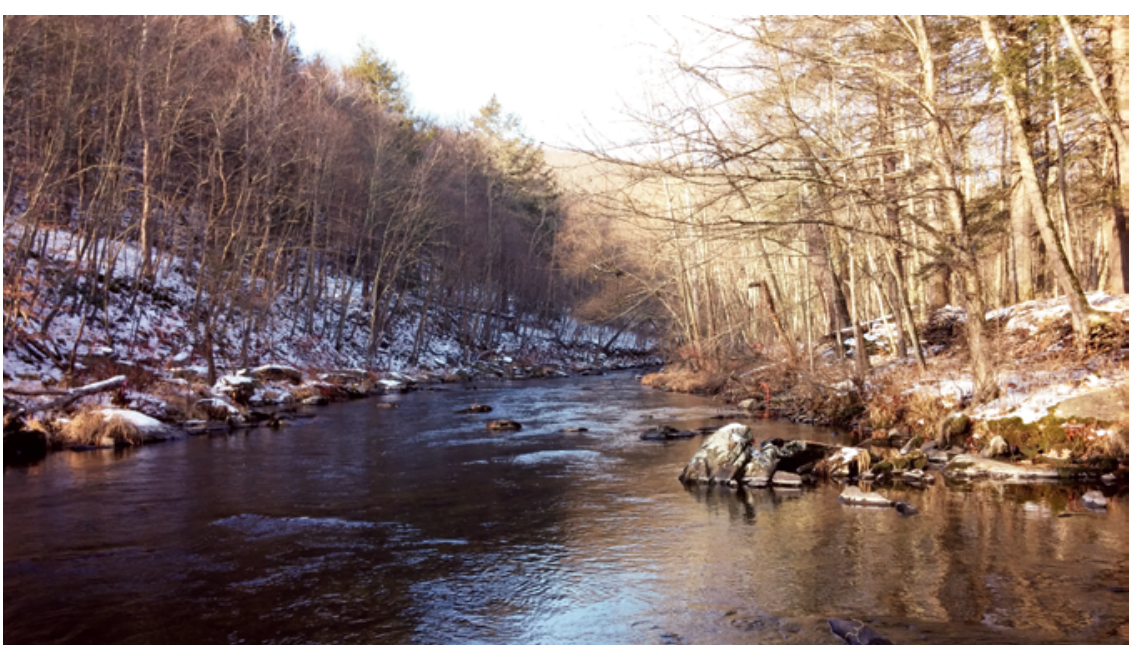

View looking downstream at the reach of Brodhead Creek at station 340.

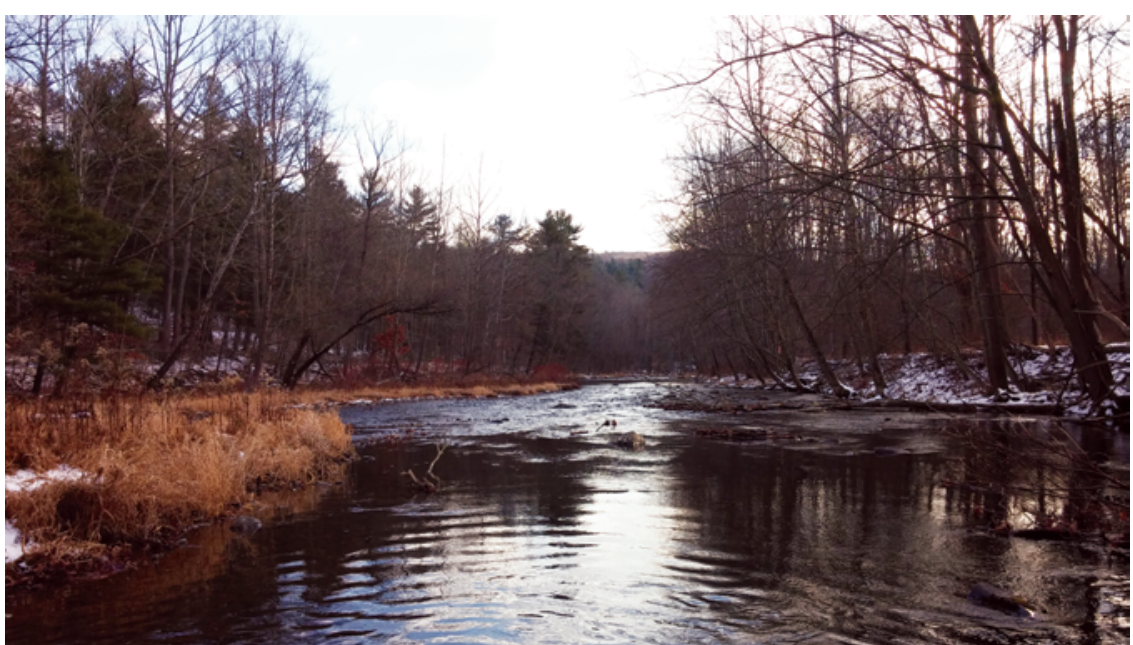

View looking downstream at the reach of Brodhead Creek at station 948.

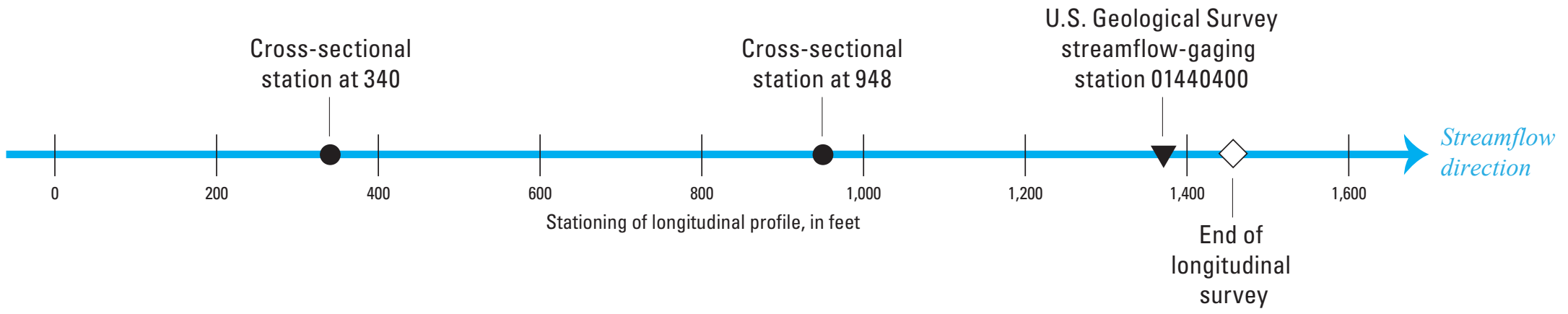

\begin{tabular}{lr}
\hline \multicolumn{2}{c}{ Cross-sectional data at station 948 } \\
\hline Bankfull cross-sectional area (square feet) & 422.5 \\
Bankfull width (feet) & 139.0 \\
Bankfull mean depth (feet) & 3.0 \\
D50 (millimeters) & 48.0 \\
D84 (millimeters) & 123.1 \\
\hline
\end{tabular}

Bankfull width (feet)

Bankfull mean depth (feet)

D50 (millimeters)

D84 (millimeters)
4.0

122.9

D84 (millimeters) 
For additional information, contact::

Director, Pennsylvania Water Science Center U.S. Geological Survey

215 Limekiln Road

New Cumberland, PA 17070

or visit our website at: https://pa.water.usgs.gov/

Publishing support provided by the West Trenton Publishing Service Center 
